\title{
A Discussion of Possible Approaches to the Integration of Thermochemical Storage Systems in Concentrating Solar Power Plants
}

\author{
Michela Lanchi ${ }^{1, *}$, Luca Turchetti ${ }^{1}$, Salvatore Sau ${ }^{1}$, Raffaele Liberatore ${ }^{1}{ }^{\mathbb{D}}$, Stefano Cerbelli ${ }^{2}$, \\ Maria Anna Murmura ${ }^{2} \mathbb{D}$ and Maria Cristina Annesini ${ }^{2}$ \\ 1 ENEA-Italian National Agency for New Technologies, Energy and Sustainable Economic Development, \\ Via Anguillarese 301, 00123 Rome, Italy; luca.turchetti@enea.it (L.T.); salvatore.sau@enea.it (S.S.); \\ raffaele.liberatore@enea.it (R.L.) \\ 2 Department of Chemical Engineering, "Sapienza" University of Rome, Materials \& Environment, \\ Via Eudossiana 18, 00184 Rome, Italy; stefano.cerbelli@uniroma1.it (S.C.); \\ mariaanna.murmura@uniroma1.it (M.A.M.); annesini@uniroma1.it (M.C.A.) \\ * Correspondence: michela.lanchi@enea.it; Tel.: +39-(0)630483292; Fax: +39-(06)30483972
}

Received: 20 July 2020; Accepted: 11 September 2020; Published: 21 September 2020

\begin{abstract}
One of the most interesting perspectives for the development of concentrated solar power (CSP) is the storage of solar energy on a seasonal basis, intending to exploit the summer solar radiation in excess and use it in the winter months, thus stabilizing the yearly production and increasing the capacity factor of the plant. By using materials subject to reversible chemical reactions, and thus storing the thermal energy in the form of chemical energy, thermochemical storage systems can potentially serve to this purpose. The present work focuses on the identification of possible integration solutions between CSP plants and thermochemical systems for long-term energy storage, particularly for high-temperature systems such as central receiver plants. The analysis is restricted to storage systems potentially compatible with temperatures ranging from 700 to $1000{ }^{\circ} \mathrm{C}$ and using gases as heat transfer fluids. On the basis of the solar plant specifications, suitable reactive systems are identified and the process interfaces for the integration of solar plant/storage system/power block are discussed. The main operating conditions of the storage unit are defined for each considered case through process simulation.
\end{abstract}

Keywords: thermochemical storage; concentrated solar power plants; concentrated solar thermal plants; storage integration; oxides decomposition; carbonates calcination; oxides carbonation

\section{Introduction}

The possibility of providing 24-h continuous supply of solar energy is a key factor in the development of concentrated solar power (CSP) technologies [1].

The currently available thermal energy storage solutions for CSP plants can achieve these results in specific contexts, but a more ambitious objective is the realization of long-term storage systems that can stabilize the seasonal production of CSP installations and increase their capacity factors. Seasonal storage is particularly interesting for the southern European latitudes, where the average values of the direct normal irradiance during the summer can be three times as high as during the winter [2]; the adoption of a long-term storage system could significantly reduce plant oversizing or fossil fuel integration, thus contributing to the reduction of production costs and the increase of the renewable energy share. Regarding the seasonal storage at medium and high temperatures $\left(>400{ }^{\circ} \mathrm{C}\right)$, thermochemical storage (TCS) systems have attracted growing attention in recent years because of some potential remarkable advantages, such as high energy density and long storage time [3]; in fact, 
these systems are activated only under certain conditions of pressure and temperature and in the presence of specific reagents.

To date, most works on TCS have been focused on fundamental studies on the reactive materials, including their stability and cyclability under the operating conditions of the storage systems, and their intrinsic storage capacity. Particularly the attention has been focused on oxides (principally manganese [4] and cobalt [5], and more recently others like ceria based oxides [6]), hydroxides (mainly calcium [7] and magnesium [8] based hydroxide), and carbonates (calcium [9,10] and magnesium [11] based carbonates), from fundamental chemical development and characterization [12] to the analysis and testing at the component level [13-18].

On the other hand, there is a lack of works devoted to the analysis of the integration between CSP plants and TCS units. Strohle et al. [19] focused on the restrictions imposed by the choice of the reactor type, i.e., packed bed or fluidized bed reactor, on the CSP/TCS integration when employing the $\mathrm{Mn}_{2} \mathrm{O}_{3} / \mathrm{Mn}_{3} \mathrm{O}_{4}$ system. To this end, the authors developed detailed models of the reactors and made less severe assumptions on the variables characterizing the other elements of the thermal energy storage systems, including the assumption that the temperature of the fluid leaving the solar field equals that of the fluid fed to the TCS unit, even in presence of an intermediate heat exchanger, and that the storage unit provides heat at temperatures that are sufficiently high to run the power block.

The objective of this work mainly lies in the discussion of possible integration approaches between solar plants and thermo-chemical systems in view of long-term energy storage, taking also into account the process constraints coming from the solar plant and the power block. The analysis is focused on central receiver systems using gaseous heat transfer fluids (HTFs), considering operating temperatures ranging from 700 to $1000{ }^{\circ} \mathrm{C}$. On the basis of the solar plants specifications, suitable reacting systems were identified and the process interfaces preliminarily discussed. In particular, the analysis is aimed at understanding the feasibility of direct contact schemes, in which the same gas is used as heat transfer fluid in the solar receiver and TES unit and as working fluid in the power block. This solution provides an advantage in terms of energy efficiency and plant simplicity, but it introduces several constraints regarding the operating pressures and temperatures. A preliminary technical discussion of such integration may be carried out without an in-depth model of the reactor, in order to narrow down the choice of configurations that are worthy of further investigation. Obviously, the final design of the system also requires detailed information on reaction kinetics and characteristics of the reactor design, which will be the object of a future work. In the present analysis the attention is placed on the identification of possible integration schemes between the solar plant and thermochemical unit with the evaluation of the main process parameters (particularly temperature and pressure) of the reactor.

\section{Process Integration}

The process interfaces for the integration of CSP technologies with thermochemical storage systems can be numerous and depend on the specifications and operating conditions of the CSP plant. Here, the attention will be focused on two main parameters for the definition of a suitable chemical storage system, namely, the maximum operating temperature of the CSP plant and the type of heat transfer fluid. In commercial CSP plants, the maximum operating temperature ranges from $390^{\circ} \mathrm{C}$ (parabolic trough plants using thermal oil as HTF) to $565^{\circ} \mathrm{C}$ (solar tower plants with molten salts as HTF); however, in demonstration plants equipped with open volumetric receivers, temperatures of the order of $1000{ }^{\circ} \mathrm{C}$ can be achieved using air as HTF [20-24].

In the present study, to limit the analysis to high temperature levels and large scale plants, the attention is only focused on the central receiver technology.

Considering a maximum operating temperature of $1000^{\circ} \mathrm{C}$ for the gaseous heat transfer fluid of the central tower plant $[25,26]$, the compatible reactive materials can be oxides or carbonates. 


\section{Thermodynamics and Possible Process Configurations}

The basic idea for a TCS system is to use a reversible chemical reaction, typically involving solid species, with a high reaction enthalpy:

$$
R_{(s)} \rightleftharpoons C_{(s)}+G_{(g)} \Delta H_{r}>0
$$

During the charging phase, the solar energy is used for the endothermic reaction to convert the solid $R$ in solid $C$ and gaseous product $G$ with higher enthalpy, which are then stored separately. In the discharging phase, $C$ and $G$ are contacted again under suitable temperature and pressure conditions, so that the reverse reaction occurs with the release of heat. From a thermodynamic point of view, according to the phase rule, the reactive system at the equilibrium has one degree of freedom, i.e., it is possible to identify on the T-P plane a single equilibrium curve, as reported in Figure 1a,b. If the point corresponding to the temperature and partial pressure of $G$ lies below the equilibrium curve, the endothermic decomposition of $R$ occurs, with a driving force given by the difference $p_{G}^{e q}-p_{G}$ and a positive heat of reaction; on the other hand, if the operating point lies above the equilibrium curve, $R$ will be produced with a driving force given by $p_{G}-p_{G}^{e q}$ and the release of heat of reaction. Therefore, it is possible to realize a cyclic process, alternating endothermic charging and exothermic discharging phases, either in thermal swing (Figure 1c) or pressure swing mode (Figure 1d).

It is evident that a reaction is suitable for application in a thermochemical storage process if it is strongly endothermic and the equilibrium constant is high at the temperature of the solar technologies employed. When operating in the thermal swing mode, thermal energy is released at a temperature lower than that of the charging phase. It is advisable that this temperature gap be as low as possible, in order to have a high global exergetic efficiency; indeed, it is possible to modulate the partial pressure of the gaseous component to reduce the thermal gap between the charging and discharging phases and to adjust the reaction temperature according to the process specifications.

The reactive material may be confined in an adiabatic reactor (fixed bed or fluidized bed) or can circulate within the plant to be directly irradiated into the solar receiver (Figure 2). In the first case, the heat required by the endothermic reaction is transferred to the chemical system by the process fluid in an adiabatic reactor, whereas in the second case the concentrated solar radiation directly invests the reacting material. Clearly, the directly irradiated system virtually enables to store solar heat with high global exergetic efficiency, while the use of an adiabatic reactor, which degrades the quality of the solar energy stored due to the inevitable reduction in the operating temperature levels, leads to a simple and robust plant configuration.

The chemical plant may have a closed or open configuration: in the first case the reacting materials are cyclically produced, stored, and consumed, while in the second case, the reaction products are removed from the plant. The open loop option is particularly suitable for oxi-reduction thermochemical systems, especially if air represents the heat transfer fluid: the oxygen produced by the reduction step can be released into the atmosphere, with undeniable advantages for plant simplicity.

With regards to the integration between the thermochemical storage unit, the CSP plant, and the power block, two main configurations are possible, if the solar energy is captured, stored, and used in the same site: series (Figure 3) and parallel (Figure 4) schemes.

The option of connection in series requires, in the charging phase (Figure 3a), different and complementary temperature ranges for the storage unit $\left(T_{3}-T_{2}\right)$ and the power block $\left(T_{4}-T_{3}\right)$ : the TCS unit is powered by high-temperature heat while the power unit is powered at a lower temperature level. Therefore, in the heat releasing step, the operating conditions of the power block may remain virtually unchanged; in fact, maintaining the same operating pressure, the thermal level of the exothermic reaction (discharging) is always lower than the temperature of the endothermic reaction (charging). 

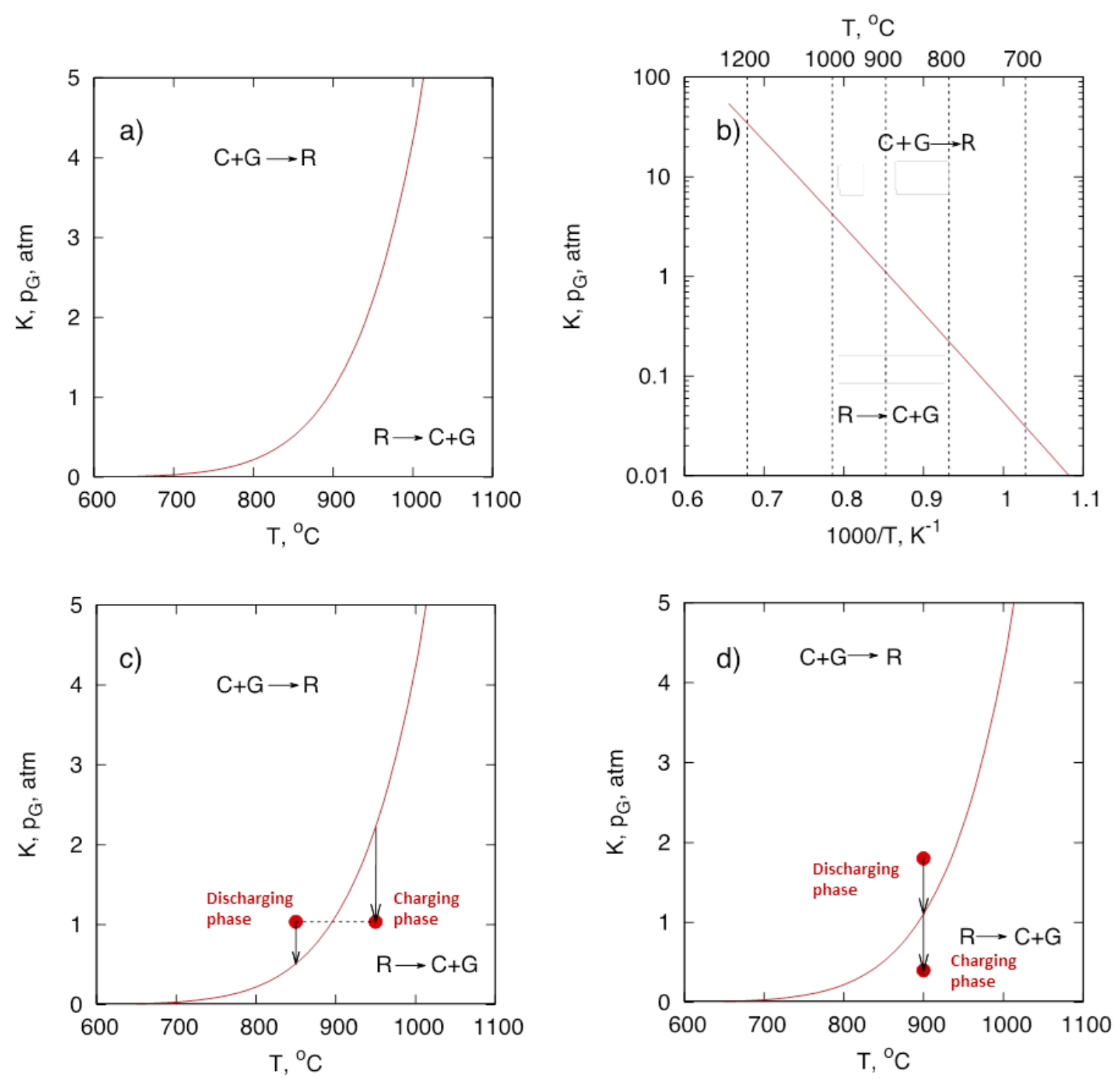

Figure 1. Thermodynamics of thermochemical storage for gas-solid systems: (a) P vs. T diagram; (b) P vs. 1/T diagram; (c) temperature swing mode; (d) pressure swing mode.

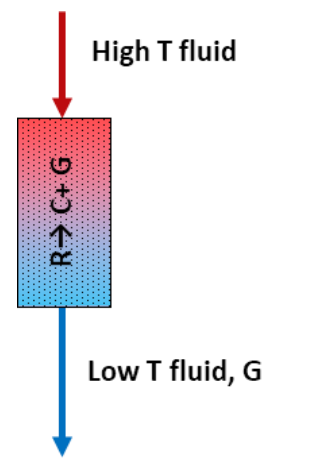

(a)

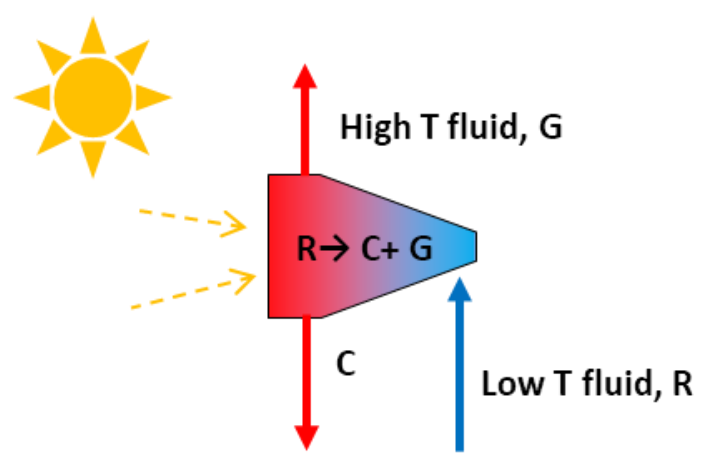

(b)

Figure 2. (a) Conceptual scheme of adiabatic reactor (fixed or fluidized bed); (b) Conceptual scheme of directly irradiated reactor. 


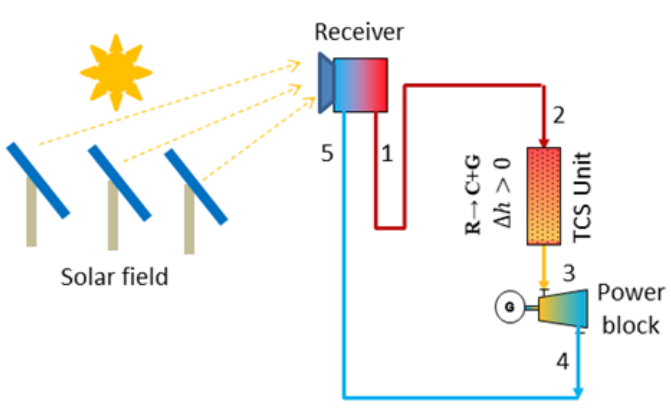

(a)

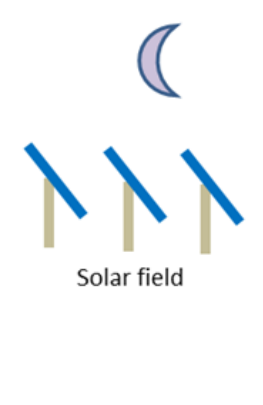

(b)

Figure 3. Conceptual scheme for the integration in series between thermochemical storage and power block, (a) charging operation (on-sun); (b) discharging operation (off-sun).

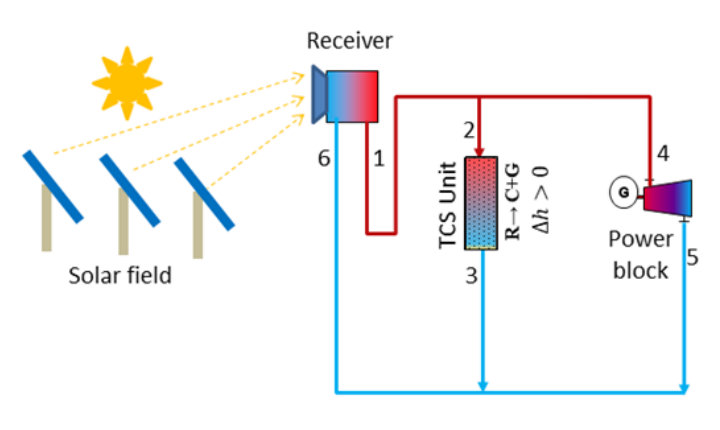

(a)

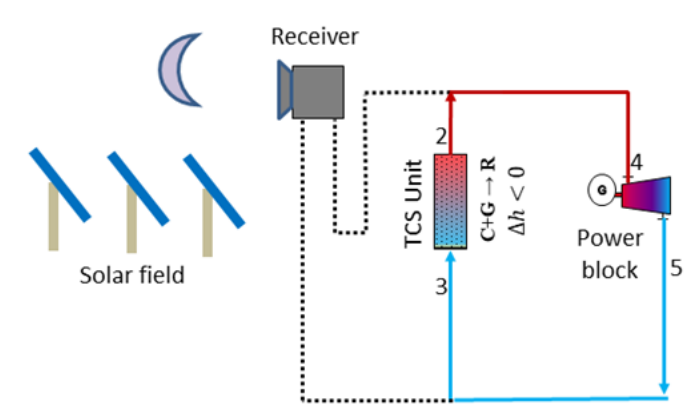

(b)

Figure 4. Conceptual scheme for the integration in parallel between thermochemical storage and power block, (a) charging operation (on-sun); (b) discharging operation (off-sun).

In the parallel scheme (Figure 4) the temperature ranges of the thermochemical storage and the power block have to be quite aligned $\left(T_{3}-T_{2} \approx T_{5}-T_{4}\right)$ to keep an overall high exergetic efficiency. Compared to the series integration scheme, this process option provides a higher flexibility in the repartition of the stored power $P_{s t}$ and the consumed power $P_{u t}$, defined by the following equations:

$$
\begin{gathered}
P_{s t}=m_{s t} c_{g}\left(T_{2}-T_{3}\right) \\
P_{u t}=m_{u t} c_{g}\left(T_{5}-T_{4}\right) \\
P_{t o t}=m_{t o t} c_{g}\left(T_{1}-T_{5}\right) P_{t o t}=m_{t o t} c_{g}\left(T_{1}-T_{5}\right)
\end{gathered}
$$

where $T_{1}$ is the temperature at the outlet of the solar receiver, $T_{2}$ and $T_{3}$ are the temperatures of the streams entering and exiting the storage unit, respectively, and $T_{4}$ and $T_{5}$ are the temperatures of the streams entering and exiting the power block, respectively; $c_{g}$ is the heat capacity of the heat transfer fluid, $m_{s t}$ and $m_{u t}$ the inlet mass flow to the TCS and the power block, respectively, $m_{t o t}$ the mass flow entering the receiver, corresponding to the sum of $m_{s t}$ and $m_{u t}$, and $P_{t o t}$ the power absorbed by the receiver $\left(P_{s t}+P_{u t}\right)$. The ratio between $P_{s t}$ and $P_{u t}$ can be modulated through the regulation of the mass flow $m_{s t}\left(=m_{2}\right)$ and $m_{u t}\left(=m_{4}\right)$.

In practice, the two temperature ranges, $T_{3}-T_{2}$ and $T_{5}-T_{4}$, cannot be homogeneous since $T_{3}$ is usually greater than $T_{5}$. This means that the temperature of the stream entering the solar field $\left(T_{6}\right)$ is an intermediate value between $T_{3}$ and $T_{4}$ : neglecting the variability of heat capacities with temperature and the possible change in composition of the $m_{s t}$ e $m_{u t}$ streams, the temperature $T_{6}$ can be calculated through the following relation:

$$
T_{6}=\frac{m_{u t} T_{5}+m_{s t} T_{3}}{m_{t o t}}
$$


From the previous equations it is possible, having fixed the target $P_{s t} / P_{u t}$ ratio, to identify the corresponding $m_{s t} / m_{u}$ ratio at various temperature differences $\Delta T_{s t}\left(T_{3}-T_{2}\right)$ and $\Delta T_{u}\left(T_{5}-T_{4}\right)$.

In the discharging phase (Figure $4 \mathrm{~b}$ ) the power block can elaborate the same temperature differences as the charging step only through the increase of the operating pressure, if feasible.

An "optimized" variant of this scheme can use different reactive materials, arranged in series and operating in complementary thermal levels, in order to make the $T_{4}-T_{2}$ and $T_{5}-T_{6}$ temperature ranges homogeneous. The stratification of the materials could take place in the same reactor or in separate systems, depending on the operating pressure and system requirements. Another possibility is the introduction of a latent or sensible heat storage downstream of the thermochemical accumulation to cover the whole temperature range available. Finally, an alternative integration solution consists in a combination of schemes in series and parallel, as shown in Figure 5: the alignment in series of the chemical reactor and power block can achieve similar enthalpy changes between streams 2 and 4 and streams 5 and 6 , while the parallel connection between the main power block and the TCS unit can introduce a margin of flexibility in the plant operation. This implies, however, a different conversion efficiency of the two power blocks, which operate at different temperature levels.

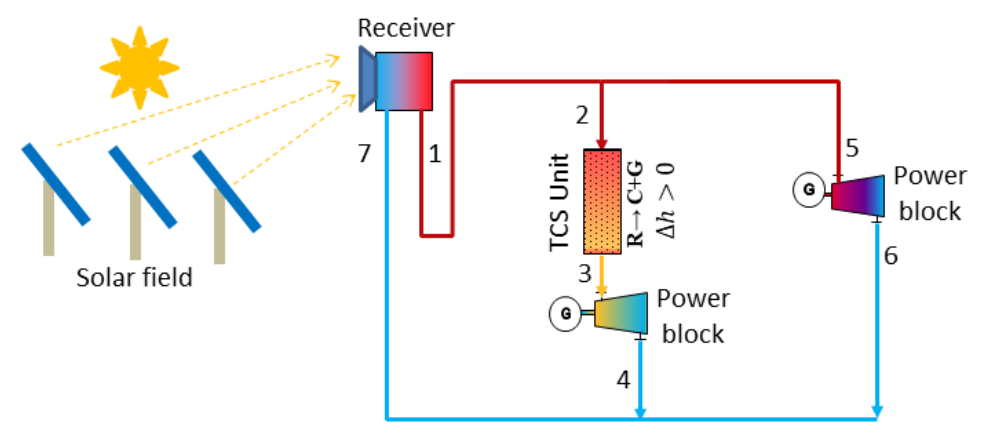

Figure 5. Conceptual scheme of "combined series/parallel" integration between thermochemical storage and power block.

The selection of the best interface between the CSP plant and the suitable reacting systems clearly requires, in addition to the in-depth thermodynamic analysis here presented, an accurate kinetic characterization of the reacting media, a detailed process design, and a realistic cost estimation, which go beyond the objective of this work. In the following, therefore, some potential integration options are considered, with the identification of possible reacting materials and the definition of preliminary process schemes, together with the identification of the operating conditions of the TCS charging and discharging steps, mainly on the basis of thermodynamic considerations.

The proposed integration schemes refer to steady state conditions and do not take into account transients operations (start-up, shut-down and off-design conditions). Therefore, in the discharging phase, the initial transient heating step, most probably carried out through the use of an external back-up heater, is not taken into account.

For the identification of reactive systems compatible with the central tower technology [27], a thermodynamic analysis is reported in the following paragraph. Regarding the preliminary definition of the operating conditions of the charging and discharging steps, in each considered case the process simulation of the entire system was carried out using the simulation tool Aspen Plus. In particular, from the process analysis, suitable values of the following operation parameters related to the TCS unit were identified:

- Inlet pressure $P_{\text {tot, in }}$

- Inlet temperature $T_{\text {in }}$;

- Outlet temperature $T_{\text {out }}$;

- $\quad$ Ratio of the thermal energy stored/released to the molar inlet flow $Q_{s t} / m_{s t}$; and

- Ratio of the molar inlet flow to the solid reaction rate $m_{s t} / v_{r x}$. 
The latter parameter can be taken as a reference, in the future, for calculating the duration of the TCS unit operation knowing the mass flow circulating in the solar system and the associated absorbed/released power. Indeed, the objective of this exploratory phase of the work is limited to the identification of the operating characteristics of the TCS system regardless of the solar plant dynamics and control logic, this topic being the aim of a more focused and detailed future analysis.

\section{Screening and Identification of Suitable Reactive Systems}

The solar tower plants currently in operation mostly make use of molten salts as heat transfer fluid, with maximum temperature levels of $500-600{ }^{\circ} \mathrm{C}$ [28]. However, more technologically complex systems are under development for the achievement of higher operating temperatures, to be virtually coupled to endothermic chemical processes, such as the reduction of metal oxides, the production of hydrogen from water splitting reactions, or the reforming of hydrocarbons [29]. For such applications, the heat transfer fluid can be represented by air or gas mixtures which transfer the solar energy to the power block and/or the endothermic reactor. In the present work it was assumed to integrate a thermochemical storage system with a high performing solar technology, operating at high temperatures, in the range $750-1000^{\circ} \mathrm{C}$. In this temperature range, two categories of reacting materials seem interesting: metal oxides and carbonates.

A preliminary screening of these materials can be carried out on the basis of the turning temperature, $T^{*}$, corresponding to the temperature at which the equilibrium pressure is 1 bar. The following relation can be easily proved:

$$
T^{*} \approx \frac{\Delta H_{298}^{0}}{\Delta S_{298}^{0}}
$$

For the selected systems, a deeper study on the equilibrium conditions was carried out in view of the definition and optimization of the integration system. Both the preliminary analysis and the study on the equilibrium conditions were mainly developed on the basis of different collections of thermodynamic data [30-33], even if specific literature data or correlations were considered in some cases. It is worth noting that different data sources are not always completely in agreement, principally due to the low rates of the gas-solid reactions, which render impractical the approach to equilibrium, the existence of several different stable and meta-stable phases, and the role of the synthesis route and physical properties of the obtained materials on their chemical activity.

As for the metal oxides, a wide list of reacting systems, generally subject to the following oxi-reduction equilibrium have been reviewed in the literature [34]:

$$
\mathrm{MeO}_{x} \rightleftarrows \mathrm{MeO}_{y}+\frac{x-y}{2} \mathrm{O}_{2}
$$

In Table 1, the heat of reaction (per unit mole, per unit weight and per unit volume of reacting solid) and the entropy of reaction at $298 \mathrm{~K}$ are reported, while in Figure 6, the heat of reaction is plotted vs. the estimated turning temperature for different reactive systems. A roughly linear correlation is shown between the heat of reaction and the turning temperature, which correspond to an almost constant value of $\Delta S_{298}^{0}$ (about $230 \mathrm{~kJ} / \mathrm{mol}$ ).

Systems based on manganese, cobalt, and copper oxides seem to be interesting for integration with solar tower technologies. Some issues are reported in literature about the reversibility of the reaction $\mathrm{MnO}_{2} / \mathrm{Mn}_{2} \mathrm{O}_{3}$ or about the possibility to work with $\mathrm{CuO} / \mathrm{Cu}_{2} \mathrm{O}$ near the melting temperature of $\mathrm{Cu}_{2} \mathrm{O}$ [34]. Therefore, the focus here is placed on the $\mathrm{Co}_{3} \mathrm{O}_{4} / \mathrm{CoO}$ and $\mathrm{Mn}_{2} \mathrm{O}_{3} / \mathrm{Mn}_{3} \mathrm{O}_{4}$ systems. 
Table 1. Heat and entropy of reaction for the most relevant metal oxide systems from [30-35].

\begin{tabular}{|c|c|c|c|c|}
\hline & \multicolumn{3}{|c|}{$\Delta H_{298}^{0}$} & \multirow{2}{*}{$\begin{array}{c}\Delta S_{298}^{0} \\
\mathrm{~J} / \text { mole K }\end{array}$} \\
\hline & $\mathrm{kJ} / \mathrm{mol}$ & $\mathrm{kJ} / \mathrm{g}$ & $\mathrm{kJ} / \mathrm{cm}^{3}$ & \\
\hline $2 \mathrm{Li}_{2} \mathrm{O}_{2} \leftrightarrows 2 \mathrm{Li}_{2} \mathrm{O}+\mathrm{O}_{2}$ & 67 & 0.74 & 1.70 & 167 \\
\hline $2 \mathrm{PbO}_{2} \leftrightarrows 2 \mathrm{PbO}+\mathrm{O}_{2}$ & 112 & 0.24 & 2.22 & 198 \\
\hline $2 \mathrm{Sb}_{2} \mathrm{O}_{5} \leftrightarrows 2 \mathrm{Sb}_{2} \mathrm{O}_{4}+\mathrm{O}_{2}$ & 128 & 0.20 & 0.76 & 208 \\
\hline $4 \mathrm{MnO}_{2} \leftrightarrows 2 \mathrm{Mn}_{2} \mathrm{O}_{3}+\mathrm{O}_{2}$ & 162 & 0.47 & 2.35 & 213 \\
\hline $2 \mathrm{BaO}_{2} \leftrightarrows 2 \mathrm{BaO}+\mathrm{O}_{2}$ & 161 & 0.48 & 2.72 & 159 \\
\hline $2 \mathrm{Co}_{3} \mathrm{O}_{4} \leftrightarrows 6 \mathrm{CoO}+\mathrm{O}_{2}$ & 392 & 0.81 & 4.98 & 294 \\
\hline $2 \mathrm{Na}_{2} \mathrm{O}_{2} \leftrightarrows 2 \mathrm{Na}_{2} \mathrm{O}+\mathrm{O}_{2}$ & 190 & 1.22 & 3.42 & 165 \\
\hline $2 \mathrm{MnO}_{2} \leftrightarrows 2 \mathrm{MnO}+\mathrm{O}_{2}$ & 269 & 1.55 & 7.80 & 218 \\
\hline $6 \mathrm{Mn}_{2} \mathrm{O}_{3} \leftrightarrows 4 \mathrm{Mn}_{3} \mathrm{O}_{4}+\mathrm{O}_{2}$ & 202 & 0.21 & 1.22 & 164 \\
\hline $4 \mathrm{CuO} \leftrightarrows 2 \mathrm{Cu}_{2} \mathrm{O}+\mathrm{O}_{2}$ & 282 & 0.89 & 5.60 & 219 \\
\hline $6 \mathrm{Fe}_{2} \mathrm{O}_{3} \leftrightarrows 4 \mathrm{Fe}_{3} \mathrm{O}_{4}+\mathrm{O}_{2}$ & 471 & 0.49 & 2.56 & 265 \\
\hline $2 \mathrm{Mn}_{3} \mathrm{O}_{4} \leftrightarrows 6 \mathrm{MnO}+\mathrm{O}_{2}$ & 464 & 1.01 & 4.93 & 252 \\
\hline
\end{tabular}

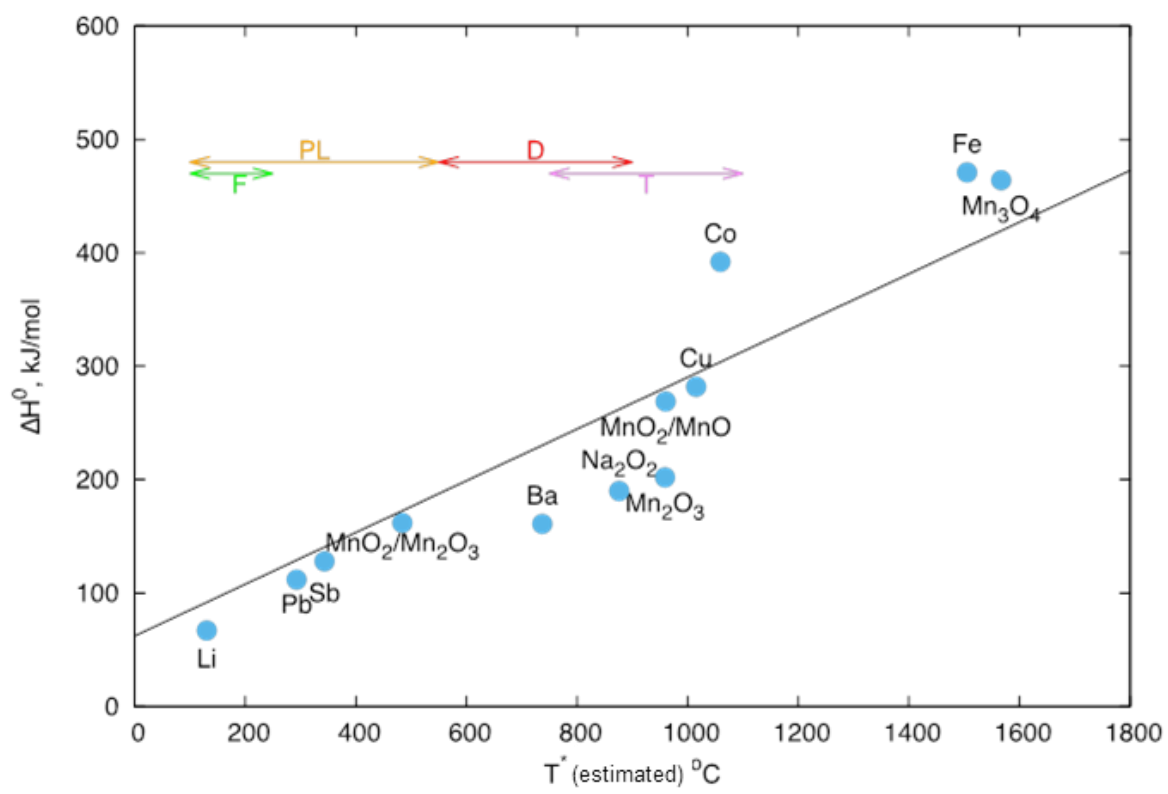

Figure 6. Heat of reaction vs. estimated turning temperature for different metal oxides systems, with indication of the operating temperature ranges for the main Concentrated Solar Thermal technologies: Fresnel (F), Parabolic trough (PL), Dish (D), Solar Tower (T).

In Figure 7, the equilibrium conditions for these systems are reported. The different slopes of the lines highlight the different values of the heat of reaction: indeed, the $\mathrm{Co}_{3} \mathrm{O}_{4} / \mathrm{CoO}$ system shows the highest heat density among the oxide systems considered and therefore is particularly attractive for thermochemical storage purposes. It is worth noting that several authors [36-38] reported that almost complete oxidation and reduction of cobalt oxide can be obtained in air near the equilibrium temperature $\left(\left|\mathrm{T}-\mathrm{T}_{\mathrm{eq}}\right|=20-40^{\circ} \mathrm{C}\right)$, with good cycle stability [38]. Tests on a solar pilot plant were also carried out, even if in this case a conversion of only $50 \%$ was obtained [39]. 


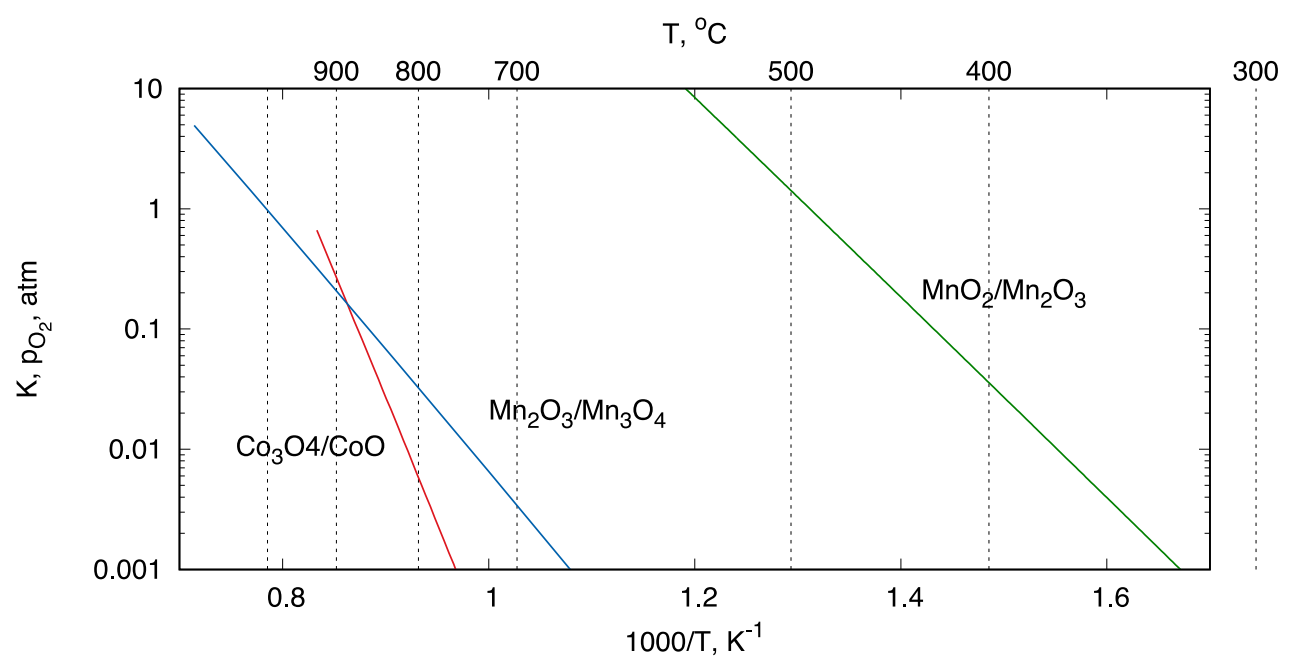

Figure 7. Thermodynamic equilibrium conditions for the cobalt oxide and manganese oxide systems.

$\mathrm{Mn}_{2} \mathrm{O}_{3}$ is less expensive, more abundant and less toxic than $\mathrm{Co}_{3} \mathrm{O}_{4}$; its reduction occurs in two steps:

$$
\begin{aligned}
6 \mathrm{Mn}_{2} \mathrm{O}_{3} & \leftrightarrows 4 \mathrm{Mn}_{3} \mathrm{O}_{4}+\mathrm{O}_{2} \\
2 \mathrm{Mn}_{3} \mathrm{O}_{4} & \leftrightarrows 6 \mathrm{MnO}+\mathrm{O}_{2}
\end{aligned}
$$

but the last one requires temperatures that are too high for its application to thermochemical storage. Therefore, only the bixbyite $\left(\mathrm{Mn}_{2} \mathrm{O}_{3}\right)$ reduction to hausmannite $\left(\mathrm{Mn}_{3} \mathrm{O}_{4}\right)$ is here considered, which has been proven to be reversible during long-term charge-discharge cycling. Some problems seem to arise from the sintering process, which causes an exponential decrease of the oxidation rate during the first cycles and a large hysteresis interval between oxidation and reduction, with a negative impact on the exergetic efficiency of the energy storage process [39]. According to recent studies, the incorporation of $\mathrm{Fe}$ and $\mathrm{Cu}$ into manganese oxides seems to improve the process performance [40].

As for carbonates, thermodynamic properties for several reactive pairs are reported in Table 2, while the heat of reaction vs. the turning temperature is plotted in Figure 8. Again, an almost linear correlation is observed, corresponding to $\Delta S_{298}^{0}=140 \mathrm{~kJ} / \mathrm{mol}$. The thermodynamic properties here reported have been evaluated using the data presented in [30].

Table 2. Heat/entropy of reaction for the most relevant carbonate-oxides, adapted from [30].

\begin{tabular}{ccccc}
\hline & \multicolumn{3}{c}{$\boldsymbol{\Delta H _ { 2 9 8 } ^ { 0 }}$} & $\Delta \boldsymbol{S}_{298}^{0}$ \\
\hline & $\mathbf{k J} / \mathbf{m o l}$ & $\mathbf{k J} / \mathbf{k g}$ & $\mathbf{k J} / \mathbf{c m}^{\mathbf{3}}$ & $\mathbf{J} / \mathbf{m o l e ~ K}$ \\
\hline $\mathrm{Li}_{2} \mathrm{CO}_{3} \leftrightharpoons \mathrm{Li}_{2} \mathrm{O}+\mathrm{CO}_{2}$ & 223 & 3.03 & 6.40 & 161 \\
$\mathrm{Na}_{2} \mathrm{CO}_{3} \leftrightharpoons \mathrm{Na}_{2} \mathrm{O}+\mathrm{CO}_{2}$ & 319 & 3.02 & 7.67 & 150 \\
$\mathrm{~K}_{2} \mathrm{CO}_{3} \leftrightharpoons \mathrm{K}_{2} \mathrm{O}+\mathrm{CO}_{2}$ & 395 & 2.86 & 6.95 & 160 \\
$\mathrm{CaCO}_{3} \leftrightharpoons \mathrm{CaO}+\mathrm{CO}_{2}$ & 178 & 1.78 & 4.83 & 159 \\
$\mathrm{MgCO}_{3} \leftrightharpoons \mathrm{MgO}+\mathrm{CO}_{2}$ & 101 & 1.20 & 3.61 & 175 \\
$\mathrm{SrCO}_{3} \leftrightharpoons \mathrm{SrO}+\mathrm{CO}_{2}$ & 236 & 1.60 & 5.97 & 171 \\
$\mathrm{BaCO}_{3} \leftrightharpoons \mathrm{BaO}+\mathrm{CO}_{2}$ & 269 & 1.36 & 5.88 & 172 \\
$\mathrm{FeCO}_{3} \leftrightharpoons \mathrm{FeO}+\mathrm{CO}_{2}$ & 75 & 0.65 & 2.55 & 181 \\
$\mathrm{PbCO}_{3} \leftrightharpoons \mathrm{PbO}+\mathrm{CO}_{2}$ & 87 & 0.33 & 2.16 & 151 \\
$\mathrm{ZnCO}_{3} \leftrightharpoons \mathrm{ZnO}+\mathrm{CO}_{2}$ & 68 & 0.55 & 2.43 & 175 \\
\hline
\end{tabular}




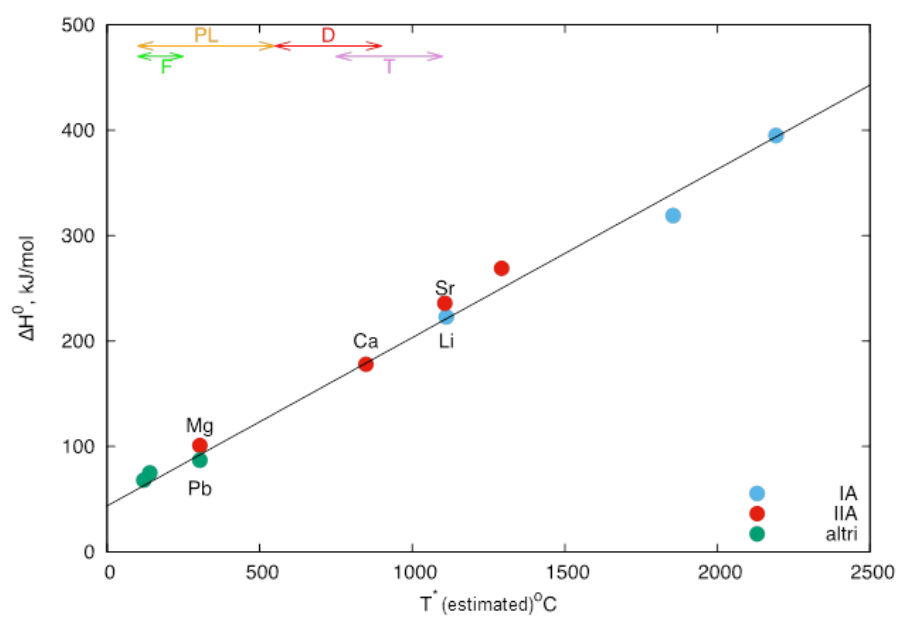

Figure 8. Heat of reaction vs. estimated turning temperature for different metal oxides systems, with indication of the operating temperature ranges for the main CST technologies: Fresnel $(\mathrm{F})$, Parabolic trough (PL), Dish (D), Solar Tower (T).

Carbonates of alkaline metals (except for $\mathrm{Li}_{2} \mathrm{CO}_{3}$ ) are too stable for thermochemical storage applications, while the reactive pair $\mathrm{CaCO}_{3} / \mathrm{CaO}$ can operate in a temperature range suitable for solar tower technologies, and $\mathrm{MgCO}_{3} / \mathrm{MgO}$ seems more compatible with lower temperature storage. Both these carbonates are particularly attractive for their availability and low cost. Equilibrium conditions of these carbonates are reported in Figure 9.

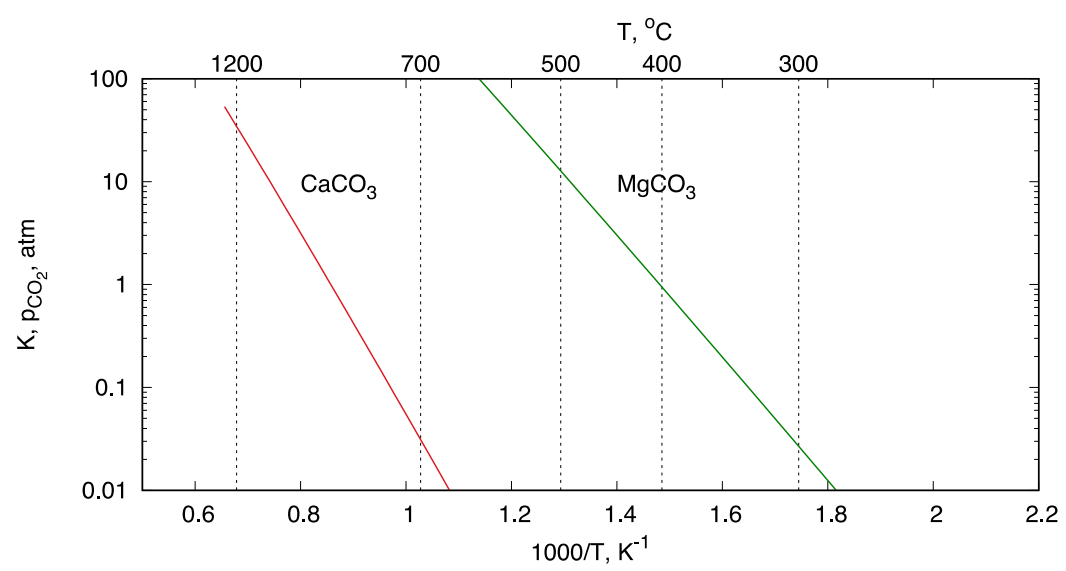

Figure 9. Thermodynamic equilibrium conditions for $\mathrm{CaCO}_{3} \mathrm{CO}_{2}$ and $\mathrm{MgCO}_{3} \mathrm{MgO}$ systems.

It is worth noting that dolomite, a double carbonate of $\mathrm{Ca}$ and $\mathrm{Mg}\left(\mathrm{CaMg}\left(\mathrm{CO}_{3}\right)_{2}\right)$, exhibits better multi-cycle properties compared to calcite. Indeed, the calcination process decomposes dolomite to $\mathrm{CaO}$ and $\mathrm{MgO}$, but the carbonation can be carried out at temperatures at which $\mathrm{MgO}$ remains inert; the $\mathrm{MgO}$ therefore provides an excess pore volume, thereby aiding the diffusion of $\mathrm{CO}_{2}$ within the particle and the kinetics of the process [41].

\section{Integration Schemes}

As mentioned above, of the possible metallic oxide systems, the cobalt oxide and manganese oxide systems developed by IMDEA [36,40] and DLR [42,43], which exhibited remarkable chemical stability and operating temperatures compatible with the tower technology, are here considered.

For the carbonate category, the calcium carbonate/calcium oxide reactive system, which has recently been studied and investigated in the field of $\mathrm{CO}_{2}$ capture techniques [44], was selected. 
For both the categories of materials it is possible to consider the use of a directly irradiated reactor or an adiabatic reactor (fixed or fluidized bed), either in a closed or open configuration of the plant.

Regarding the power block, the adoption of a Brayton gas cycle, powered directly by the solar thermal fluid, was envisaged to realize a compact and economical system configuration that allows efficient utilization of the high temperature solar energy $\left(800-1000^{\circ} \mathrm{C}\right)$. In the Brayton cycles the heat conversion efficiency into electricity is typically in the range $0.3-0.4$, depending on the thermodynamic cycle parameters and complexity of the plant. The integration with the Rankine cycle, which is operative at lower-temperatures $\left(500-250^{\circ} \mathrm{C}\right)$, can also be considered in a combined Brayton/Rankine power block.

In the present work, the direct contact scheme between thermal fluid and reactive material are considered as a first option, by virtue of its inherent plant simplicity and compactness. Nevertheless, the hypothesis of an intermediate heat exchange, which implies different thermal/process fluids and different operating pressures for the solar plant and the thermochemical storage unit, are also considered.

The different system configurations analyzed for the integration of the solar tower plant with the thermochemical unit are summarized in Table 3.

Table 3. Possible design options for the integration of the solar plant and the thermochemical storage unit.

\begin{tabular}{ccccccc}
\hline \multicolumn{2}{l}{ Central Tower Plant } & \multicolumn{2}{c}{ Thermochemical Storage Unit } & Power Plant \\
\hline $\begin{array}{l}\mathrm{T}_{\text {max }} \\
{\left[{ }^{\circ} \mathrm{C}\right]}\end{array}$ & $\begin{array}{c}\text { Thermal } \\
\text { Fluid }\end{array}$ & Reacting Material & $\begin{array}{c}\text { Process } \\
\text { Fluid }\end{array}$ & Reactor & $\begin{array}{c}\text { Plant } \\
\text { Configuration }\end{array}$ & Cycle \\
\hline Air & $\begin{array}{c}\mathrm{Co}_{3} \mathrm{O}_{4}-\mathrm{Co} \\
\mathrm{Mn}_{3} \mathrm{O}_{4}-\mathrm{Mn}_{3} \mathrm{O}_{4}\end{array}$ & Air & $\begin{array}{c}\text { Fixed/Fluidized bed } \\
\text { or Directly irradiated } \\
\text { Fixed/Fluidized bed } \\
\text { or Directly irradiated }\end{array}$ & $\begin{array}{c}\text { Open } \\
\text { Closed } \\
\text { Open }\end{array}$ & Brayton \\
Mix air/CO $/ \mathrm{CO}_{2}$ & $\mathrm{CaO}_{3}-\mathrm{CaO}$ & Mix air/ $/ \mathrm{CO}_{2}$ & Brayton \\
\hline
\end{tabular}

\section{Integration with Oxides-Based Systems}

The reacting systems under exam, $\mathrm{Mn}_{2} \mathrm{O}_{3}-\mathrm{Mn}_{3} \mathrm{O}_{4}$ and $\mathrm{Co}_{3} \mathrm{O}_{4}-\mathrm{Co}$, are characterized, respectively, by the following equilibrium reactions:

$$
\begin{gathered}
6 \mathrm{Mn}_{2} \mathrm{O}_{3} \leftrightharpoons 4 \mathrm{Mn}_{3} \mathrm{O}_{4}+\mathrm{O}_{2} \\
2 \mathrm{Co}_{3} \mathrm{O}_{4} \leftrightharpoons 6 \mathrm{CoO}+\mathrm{O}_{2}
\end{gathered}
$$

The equilibrium temperature at atmospheric pressure is high for both the systems $\left(\sim 900{ }^{\circ} \mathrm{C}\right)$; assuming the use of an adiabatic reactor in the TCS unit, this leads to a limited temperature difference between the inlet and the outlet of the thermochemical storage system (TCS unit inlet temperature: $1000{ }^{\circ} \mathrm{C}$; TCS outlet temperature: $\sim 90{ }^{\circ} \mathrm{C}$ ). A "combined series-parallel" integration scheme was considered for both the TCS systems: the introduction of a power block in series with the thermochemical storage unit allows to fully exploit the enthalpy difference between the HTF input and the output in the solar field, while the second power unit connected in parallel allows to modulate the repartition between the stored and the directly used solar energy. In addition, in the case of metal oxides, air can be used both as heat transfer fluid and as process fluid, with no intermediate exchangers between the solar system, the thermochemical storage unit and the power block, in a compact and efficient configuration. Taking into account such boundary conditions, i.e., confined adiabatic reactor, open cycle, Brayton cycle-based power plant, and combined series/parallel configuration of the power block, the process scheme initially hypothesized for the whole system is represented in Figure 10: the atmospheric air, downstream of a compression stage, is sent to the receiver to absorb the solar radiation and transform it into thermal energy. 


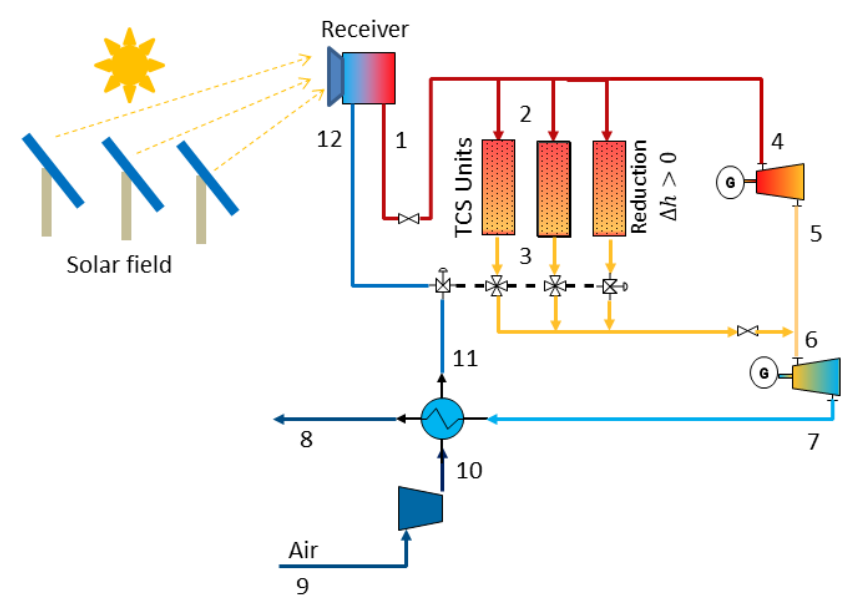

Figure 10. Integration scheme for a solar tower plant/thermochemical storage (TCS) unit (oxide systems)/ power block; on-sun operation.

The hot air coming from the receiver is partly sent to the power block and partly to the thermochemical storage unit (consisting of modular elements) to power the endothermic reduction reaction of the oxides (with oxygen release). As previously mentioned, the reactor outlet temperature is still high $\left(\mathrm{T}_{3}\right)$; therefore, the process fluid is sent to a second power block, which, depending on the thermal and pressure levels, can also be connected in series with the first power unit. Finally, through a recuperator, the gas exiting the second power block preheats the incoming air before being released into the atmosphere.

In the off-sun operating phase, the atmospheric air, after compression and preheating, is sent to the storage unit, where, through the exothermic oxidation reaction, it recovers the accumulated chemical energy, regenerating the initial reacting material. The hot air coming out of the TCS unit is then processed in the power block (or in the two power blocks in series) to produce electricity and is finally released into the atmosphere, after having preheated the incoming air.

From the T-P curves of the systems under exam, shown in Figures 7 and 9, it can be seen that in correspondence of an oxygen molar fraction of 0.21 , the maximum operating pressure for the reduction reaction (charging phase) is $1 \mathrm{~atm}$, since an equilibrium temperature of about $900{ }^{\circ} \mathrm{C}$ corresponds to this pressure level. Therefore, considering this integration scheme, it is necessary to adopt different operating pressures for the TCS unit and the power block, in order to guarantee an expansion ratio of at least 3 atmospheres in the power block. To this purpose expansion valves could be introduced upstream of the TCS unit to reduce the air pressure entering the adiabatic reactor (Figure 11).

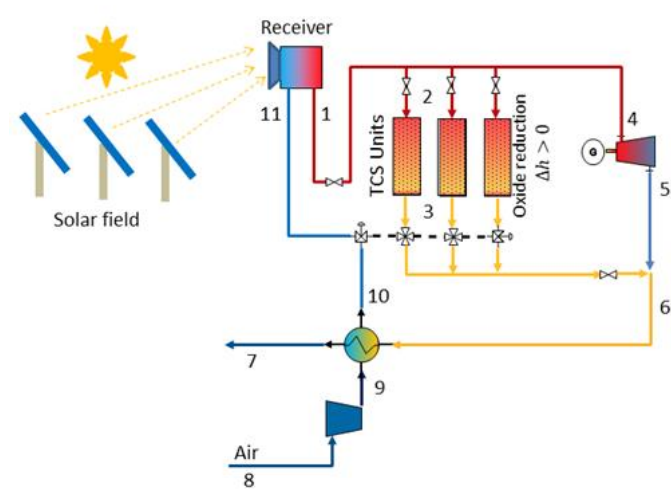

(a)

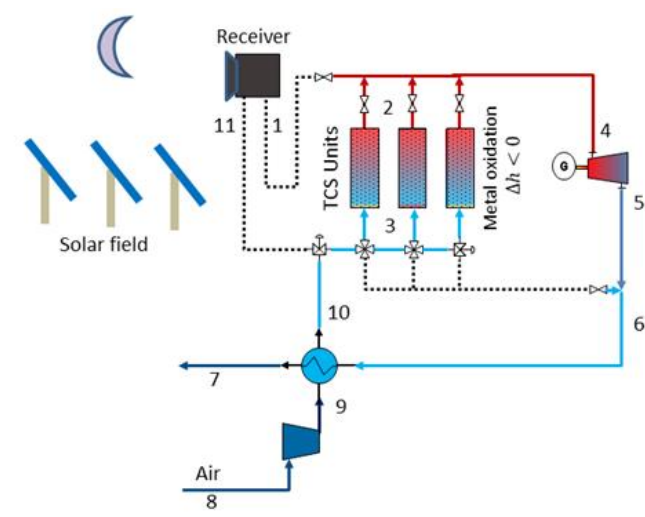

(b)

Figure 11. Integration scheme for a solar tower plant/TCS unit (oxide systems)/power block with expansion valves upstream of the reactor: (a) on-sun operation; (b) off-sun operation. 
These limitations could be overcome by using two different solar receivers and two separate circuits dedicated to thermal storage and electricity production: the two receivers, operating at different pressures, could be positioned in separate sections of the same solar tower, intercepting the radiation reflected from two different segments of the solar field. An alternative solution to decouple the operating pressures of the storage unit and the power block envisages the introduction of an intermediate heat exchange between the adiabatic reactor and the main circuit of the plant (Figure 12). This clearly implies a thermal degradation of the solar energy released by the HTF: the reactor, in the best condition, would work at a maximum temperature of $950{ }^{\circ} \mathrm{C}$ (assuming, in the intermediate exchanger, a temperature difference of $50{ }^{\circ} \mathrm{C}$ between the hot inlet and the cold outlet flows). The reactor operating pressure would be less than $1 \mathrm{~atm}$ in the charging phase and equal to $1 \mathrm{~atm}$ in the heat releasing phase. The secondary circuit of the thermochemical storage unit should therefore be equipped with a vacuum system.

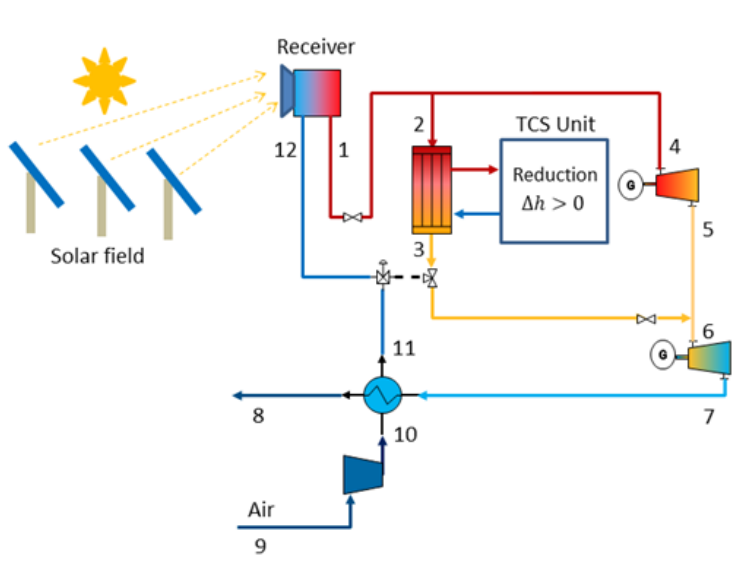

(a)

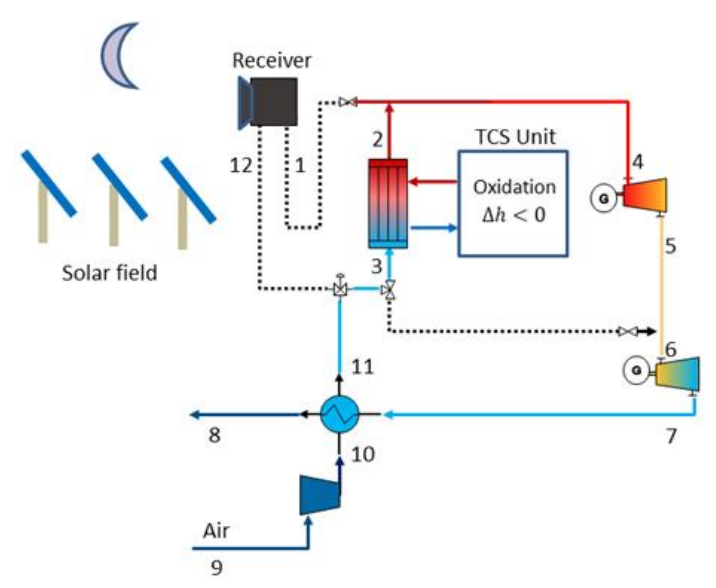

(b)

Figure 12. Indirect integration scheme for a central tower plant/TCS unit (oxide systems)/power block: (a) on-sun operation; (b) off-sun operation.

In the alternative hypothesis of employing a directly irradiated reactor, the reactive material is fed to the solar receiver through the use of specific equipment for solids handling (Figure 13). In the receiver the material is invested by the solar radiation, reacts and releases oxygen, regenerating the reduced chemical species, and is subsequently cooled and stored in a special tank. Several concepts of solid-material reactor [39,45], falling film reactor [46], fluidized bed reactor [47], swirl flow [48], etc., have been proposed in the literature, but the development of this component is still at an early stage due to the technological constraints associated with the direct irradiation (resistance of materials, quartz window sealing, differential expansion, and scalability). Depending on the type of receiver adopted, the reaction can occur under vacuum or in air flow, as shown in Figure 13. In the latter case, a better internal heat transfer and a more efficient heat-electricity conversion in the power block would be obtained.

In the hypothesis of direct irradiation, the repartition between the stored power $P_{s t}$ and the used power $P_{u t}$ can be more easily adjusted. Moreover, also in this case, in order to obtain greater operating flexibility, it is possible to operate two parallel receivers, positioned on the same central tower, dedicated both to thermochemical storage and direct production of electricity. In the absence of consolidated data on the feasibility of directly irradiated reactor/receiver, in this work the operating conditions of the storage system are defined in the hypothesis of adiabatic confined reactor, as reported below. 


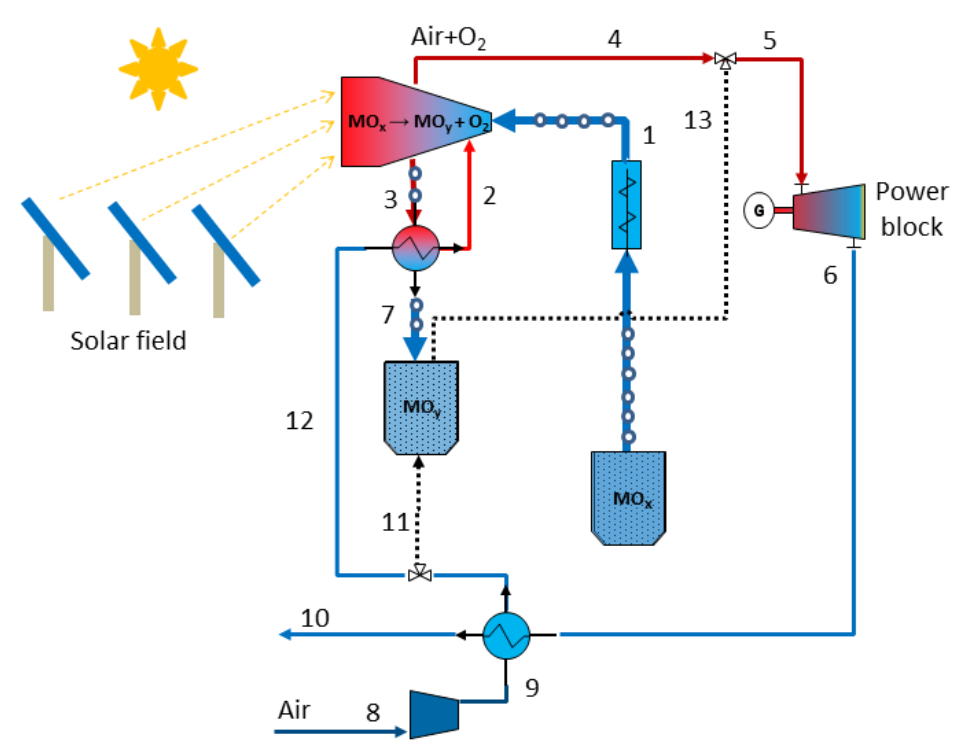

Figure 13. Integration scheme for a central tower plant/TCS unit (oxide systems)/power block; on-sun operation assuming a directly irradiated reactor.

\section{Calculation of TCS Operating Parameters}

For the preliminary definition of the operating conditions of the TCS unit, two different system configurations were taken into account: a direct contact scheme (Figure 11) and a scheme with intermediate heat exchange (Figure 12). The P-T equilibrium curves used for the two selected reactive systems, $\mathrm{Mn}_{2} \mathrm{O}_{3}-\mathrm{Mn}_{3} \mathrm{O}_{4}$ and $\mathrm{Co}_{3} \mathrm{O}_{4}-\mathrm{Co}$, are shown in Figure 7.

Regarding the charging step, in the case of the direct contact scheme (Figure 11a), it was assumed to operate the TCS unit at atmospheric pressure, which corresponds to an equilibrium temperature of $900{ }^{\circ} \mathrm{C}$ for the $\mathrm{Mn}_{2} \mathrm{O}_{3}-\mathrm{Mn}_{3} \mathrm{O}_{4}$ system and of $882{ }^{\circ} \mathrm{C}$ for the $\mathrm{Co}_{3} \mathrm{O}_{4}-\mathrm{CoO}$ system. Considering the thermodynamic constraints, the operating temperature of the reactor in the case of the $\mathrm{Mn}_{3} \mathrm{O}_{4}-\mathrm{Mn}_{2} \mathrm{O}_{3}$ system has to be always higher than $900{ }^{\circ} \mathrm{C}$ and in this work, it was assumed to be included in the range $910-1000{ }^{\circ} \mathrm{C}$. For the $\mathrm{Co}_{3} \mathrm{O}_{4}-\mathrm{CoO}$ system, the operating thermal interval is included in the range 892- $1000{ }^{\circ} \mathrm{C}$.

In the hypothesis of an indirect contact configuration (Figure 12a), assuming a temperature difference of $50{ }^{\circ} \mathrm{C}$ between the hot inlet and the cold outlet streams in the intermediate heat exchanger, and considering a realistic pressure of $0.4 \mathrm{~atm}$ in the reactor, the following operating parameters can be identified for the TCS unit:

- manganese oxide system-thermal interval: $950-860^{\circ} \mathrm{C}$, with an equilibrium temperature of $850^{\circ} \mathrm{C}$;

- cobalt oxide-thermal interval: $950-878^{\circ} \mathrm{C}$, with an equilibrium temperature of $868^{\circ} \mathrm{C}$.

Regarding the discharging phase, in the direct contact process option (Figure 11b), the system is operated at a higher pressure than the charging step to increase the temperature level at which the heat is released, to improve the oxidation reaction kinetics and to provide a suitable turbine head. The optimal operating pressure was identified through a process analysis of the entire system, shown in Figure 11b, taking into account the upstream and downstream operations of the TCS unit: for the recuperator a temperature difference of $50{ }^{\circ} \mathrm{C}$ between the cold inlet and hot outlet streams was assumed, while the power block for simplicity was represented by a turbine with an isoentropic efficiency equal to 0.85 . More specifically, a parametric analysis of the reactor operating conditions (outlet temperature and inlet air flow rate) was carried out varying the compressor outlet pressure and maintaining a reactor input temperature compatible with the oxidation kinetics (approx. $>650^{\circ} \mathrm{C}$ ). The results of the parametric analysis are summarized in Figures 14 and 15, where the equilibrium 
temperature of the systems as a function of the total pressure is also represented. These figures show that the maximum operating pressure of the adiabatic reactor is less than 2.8 atm in the case of manganese oxide, and less than $2.6 \mathrm{~atm}$ in the case of cobalt oxide; above these pressure values the corresponding system temperatures are not compatible with the equilibrium temperatures.

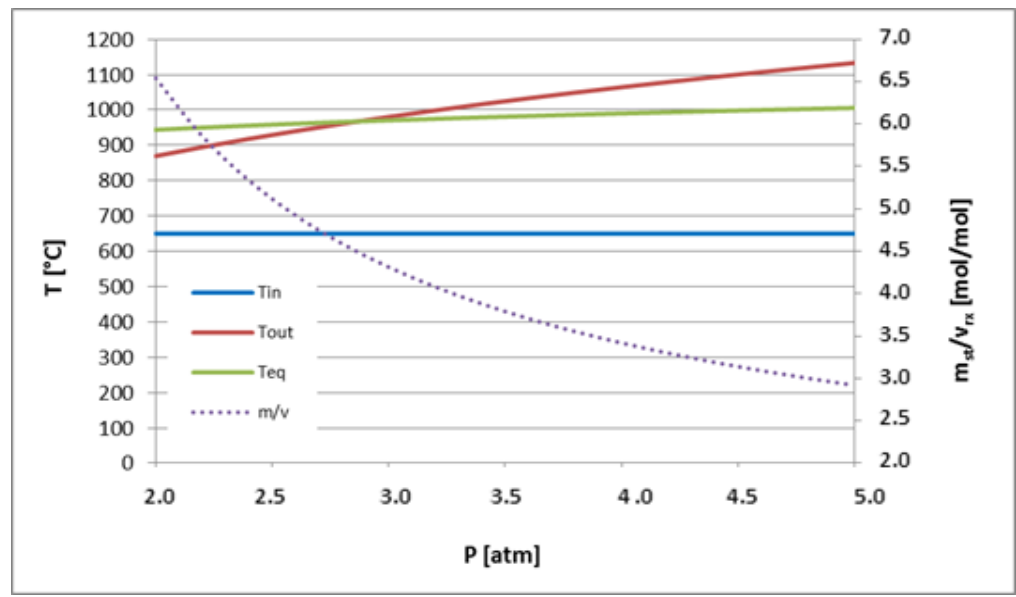

Figure 14. $\mathrm{Mn}_{2} \mathrm{O}_{3}-\mathrm{Mn}_{3} \mathrm{O}_{4}$ system (charging phase): parametric analysis of the reactor outlet temperature, reactor inlet flow, and reactor equilibrium temperature varying the inlet flow total pressure (assuming power block outlet pressure: $1 \mathrm{~atm}$ ).

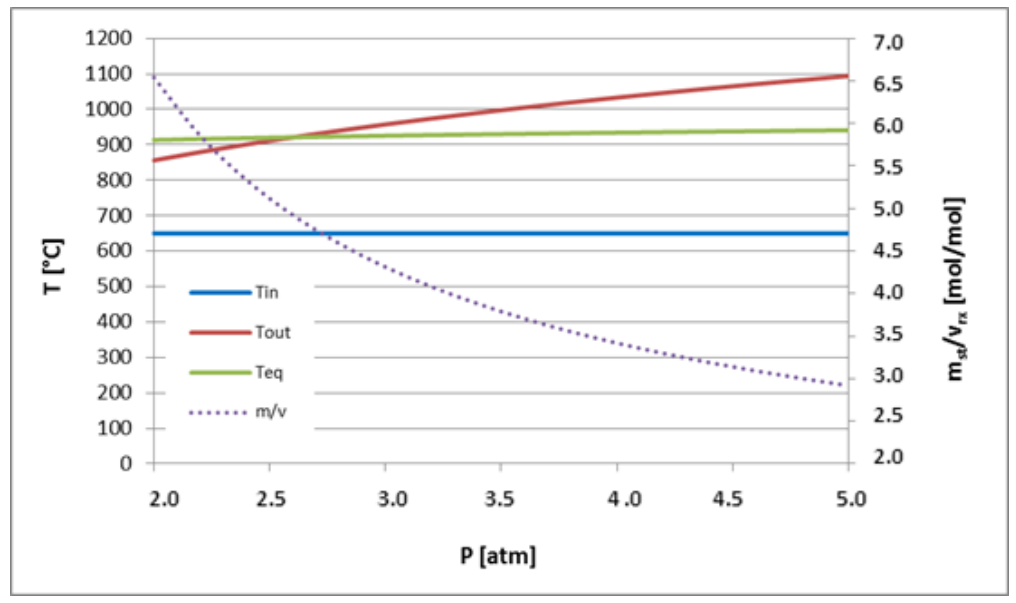

Figure 15. $\mathrm{Co}_{3} \mathrm{O}_{4} \mathrm{CoO}$ system (charging phase): parametric analysis of the reactor outlet temperature, reactor inlet flow, and reactor equilibrium temperature varying the inlet flow total pressure.

In the case of an indirect integration scheme (Figure 12), the operating pressures of the reactor in the charging $(\mathrm{P}<1 \mathrm{~atm})$ and discharging steps should not be significantly different, due to technological constraints related to the operation of the vacuum systems. It was therefore assumed, in the discharging phase, to operate the reactor at atmospheric pressure, with equilibrium temperatures of $900{ }^{\circ} \mathrm{C}$ (manganese oxide) and $882^{\circ} \mathrm{C}$ (cobalt oxide).

Considering a reactor inlet temperature of $650{ }^{\circ} \mathrm{C}$, and a minimum temperature difference of $10{ }^{\circ} \mathrm{C}$ between the reactor outlet temperature and the reaction equilibrium temperature, the operating temperature range of the TCS system is included in the range $650-890{ }^{\circ} \mathrm{C}$ for the manganese oxide and 650-872 ${ }^{\circ} \mathrm{C}$ for the cobalt oxide. Consequently, the thermal difference of the HTF in the intermediate heat exchanger is approximately $600-840{ }^{\circ} \mathrm{C}$ for the manganese oxide and $600-822^{\circ} \mathrm{C}$ for the cobalt oxide, assuming equal flow rates of the inlet stream. Tables 4 and 5 summarize the main operating parameters of the storage units, identified through the process simulation of the entire systems and referring to the cases mentioned above. From the comparison of the operating conditions reported in 
these tables, it clearly emerges that the direct heat exchange scheme has higher "storing" efficiency than the alternative case (indirect heat exchange) since the amount of heat absorbed and released per air mole is higher. On the other hand, in the direct scheme, the constraints on the reactor operating pressure lead to significant limitations on the overall efficiency of the system: in the charging phase the introduction of expansion valves upstream the TCS unit causes a reduction in the mechanical work obtainable in the turbine, while in the discharging phase the maximum input pressure at the power block is less than $2.6 \mathrm{~atm}$, resulting in a limited expansion ratio in the turbine.

Table 4. TCS operating conditions for the manganese oxide system (open cycle and adiabatic reactor).

\begin{tabular}{|c|c|c|c|c|}
\hline \multirow{2}{*}{$\begin{array}{c}\mathrm{Mn}_{3} \mathrm{O}_{4}-\mathrm{Mn}_{2} \mathrm{O}_{3} \text { System } \\
\Delta H_{r x}: 31.9 \\
\left(\mathrm{~kJ} / \mathrm{mol}_{\mathrm{Mn2O3}}\right)[34]\end{array}$} & \multicolumn{2}{|c|}{ Charging Phase } & \multicolumn{2}{|c|}{ Discharging Phase } \\
\hline & $\begin{array}{c}\text { Direct Heat } \\
\text { Exchange }\end{array}$ & $\begin{array}{c}\text { Indirect Heat } \\
\text { Exchange }\end{array}$ & $\begin{array}{c}\text { Direct Heat } \\
\text { Exchange }\end{array}$ & $\begin{array}{c}\text { Indirect Heat } \\
\text { Exchange }\end{array}$ \\
\hline$x_{O 2, \text { in }}(\mathrm{mol} / \mathrm{mol})$ & 0.21 & 0.21 & 0.21 & 0.21 \\
\hline$P_{t o t, i n}(\mathrm{~atm})$ & 1.0 & 0.4 & 2.6 & 1.0 \\
\hline$T_{e q}\left({ }^{\circ} \mathrm{C}\right)$ & 900 & 850 & 962 & 900 \\
\hline$T_{i n}\left({ }^{\circ} \mathrm{C}\right)$ & 1000 & 950 & 650 & 650 \\
\hline$T_{\text {out }}\left({ }^{\circ} \mathrm{C}\right)$ & 910 & 860 & 940 & 890 \\
\hline$m_{s t} / v_{r x}\left(\mathrm{~mol}_{\text {gas }} / \mathrm{mol}_{\mathrm{s}}\right)$ & 10.3 & 10.3 & 4.92 & 6.0 \\
\hline$Q_{s t} / m_{s t}(\mathbf{k J} / \mathbf{m o l})$ & 3.1 & 3.1 & 9.7 & 8.0 \\
\hline
\end{tabular}

Table 5. TCS operating conditions for the cobalt oxide system (open cycle and adiabatic reactor).

\begin{tabular}{|c|c|c|c|c|}
\hline \multirow{2}{*}{$\begin{array}{c}\mathrm{Co}_{3} \mathrm{O}_{4}-\mathrm{CoO} \text { System } \\
\Delta H_{r x}: 195 \\
\left(\mathrm{~kJ} / \mathrm{mol}_{\mathrm{Mn} 2 \mathrm{O} 3}\right)[49]\end{array}$} & \multicolumn{2}{|c|}{ Charging Phase } & \multicolumn{2}{|c|}{ Discharging Phase } \\
\hline & $\begin{array}{c}\text { Direct Heat } \\
\text { Exchange }\end{array}$ & $\begin{array}{c}\text { Indirect Heat } \\
\text { Exchange }\end{array}$ & $\begin{array}{c}\text { Direct Heat } \\
\text { Exchange }\end{array}$ & $\begin{array}{c}\text { Indirect Heat } \\
\text { Exchange }\end{array}$ \\
\hline$x_{O 2, \text { in }}(\mathrm{mol} / \mathrm{mol})$ & 0.21 & 0.21 & 0.21 & 0.21 \\
\hline$P_{\text {tot, in }}($ atm) & 1.0 & 0.4 & 2.5 & 1.0 \\
\hline$T_{e q}\left({ }^{\circ} \mathrm{C}\right)$ & 882 & 868 & 920 & 882 \\
\hline$T_{i n}\left({ }^{\circ} \mathrm{C}\right)$ & 1000 & 950 & 650 & 650 \\
\hline$T_{\text {out }}\left({ }^{\circ} \mathrm{C}\right)$ & 892 & 878 & 910 & 872 \\
\hline $\begin{array}{c}m_{s t} / v_{r x} \\
\left(\mathrm{~mol}_{\text {gas }} / \mathrm{mol}_{\mathrm{s}}\right)\end{array}$ & 54.7 & 81.4 & 7.7 & 9.8 \\
\hline$Q_{s t} / m_{s t}(\mathrm{~kJ} / \mathrm{mol})$ & 3.7 & 2.4 & 8.7 & 7.5 \\
\hline
\end{tabular}

From an engineering point of view, the solution with the intermediate exchanger certainly offers greater operational flexibility, being able to decouple the pressure levels of the power block from the storage tank, but it requires a higher investment cost for the presence of the intermediate heat exchanger. Additionally in such scheme the TCS unit should be equipped with a vacuum system and should operate in unfavorable heat/mass transfer conditions (low pressures), requiring higher volumes, and, consequently higher investment costs.

\section{Integration with Carbonates-Based Systems}

The calcium oxide/calcium carbonate system is characterized by the following equilibrium reaction:

$$
\mathrm{CaCO}_{3} \leftrightharpoons \mathrm{CaO}+\mathrm{CO}_{2}
$$

This material, which has principally been studied in the field of carbon capture techniques [50], has an equilibrium temperature of about $900{ }^{\circ} \mathrm{C}$ (at $1 \mathrm{~atm}$ ). The cyclical production and consumption of $\mathrm{CO}_{2}$ requires, in theory, the adoption of a closed loop scheme, where the thermal fluid can be either pure $\mathrm{CO}_{2}$ or air/ $\mathrm{CO}_{2}$ mixtures. On the other hand, by working at $\mathrm{CO}_{2}$ partial pressures lower than 1 atm, it is possible to significantly reduce the thermal level of the calcination step and, in the hypothesis of carrying out the reaction under an air flow, the equilibrium temperature falls below $700{ }^{\circ} \mathrm{C}$ (Figure 9 ). 
Therefore, in the present paper, two process options, closed cycle (with $\mathrm{CO}_{2}$ recycling) and open cycle, represented in Figure 16 and Figure 18, respectively, have been taken into account. It is worth pointing out that the latter option, as a whole process, is characterized by a neutral $\mathrm{CO}_{2}$ balance since the carbon dioxide released during the solar working phase has been previously absorbed in the off-sun operation from gaseous effluents produced in combustion or oxy-combustion processes.

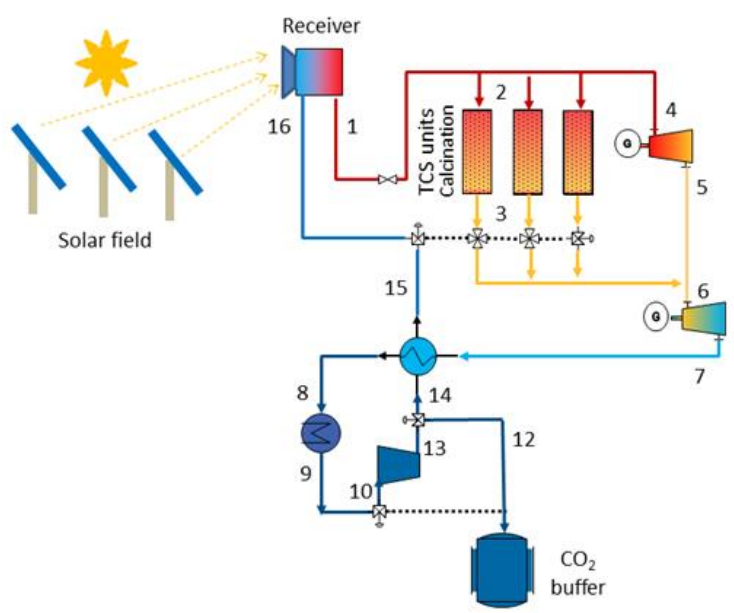

(a)

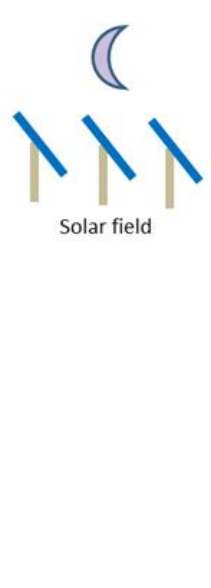

(b)

Figure 16. Conceptual scheme for the integration of a central tower plant with TCS storage unit assuming adiabatic reactor, closed process configuration, Brayton cycle-based power block. (a) on-sun operation; (b) off-sun operation.

In these schemes, the "combined series/parallel" (Figure 5) integration option between thermochemical storage and power block has been considered in order to use the whole enthalpy difference available between the inlet and the outlet of the solar field. Nevertheless, in this specific case, it could also be possible to consider a "stratified" storage unit, consisting of a stack of different chemical species characterized by different and complementary operating thermal levels, or different sensible/latent heat media, in order to increase the power stored per mass flow unit. As an example, the use of both the calcium carbonate and magnesium carbonate reacting systems could be considered in the same storage unit, where the calcium carbonate, operating at higher temperatures, represents the first accumulation stage and the magnesium carbonate, whose decomposition temperature at $1 \mathrm{~atm}$ is about $400{ }^{\circ} \mathrm{C}$, is the second step.

\subsection{Closed Loop Option: Calculation of TCS Operating Parameters}

Referring to the hypothesis of a closed loop and adiabatic reactor, in the solar operating phase (Figure 16a) the stream of air and $\mathrm{CO}_{2}$ is sent to the receiver to absorb the solar energy. The hot gas leaving the receiver is partly processed directly in the power block and partly sent to the thermochemical storage unit (consisting of modular elements) to feed the endothermic calcium carbonate decomposition reaction (with $\mathrm{CO}_{2}$ release). The stream leaving the reactor is subsequently processed in a power block or, in the case of the stratified storage, sent to a second reactive step (based on magnesium carbonate) with further production of $\mathrm{CO}_{2}$. Finally, through a recuperator, the gas leaving the power block preheats the incoming air before being further cooled, compressed and stored.

In the case of a closed loop, the cyclical production and consumption of $\mathrm{CO}_{2}$ lead to a variable gas composition over time, oscillating between the values corresponding to the end of the calcination step (maximum concentration) and the end of the carbonation step (minimum concentration). During the calcination phase, the maximum allowed $\mathrm{CO}_{2}$ pressure, and consequently the maximum $\mathrm{CO}_{2}$ concentration, depends on the outlet temperature of the adiabatic reactor, which should be below $900^{\circ}$. Assuming an equilibrium temperature of the $\mathrm{CaCO}_{3}-\mathrm{CaO}$ system is always below $900{ }^{\circ} \mathrm{C}$, in order to 
favor the decomposition reaction during the whole solar charging phase, the molar fraction of $\mathrm{CO}_{2}$ in the gas flow, for different levels of total pressure, must always be lower than/equal to the values shown in Table 6 (first and second columns). Therefore, in the hypothesis of working at a total maximum pressure lower than $5 \mathrm{~atm}$, the corresponding molar fraction of $\mathrm{CO}_{2}$ at the completion of the calcination step has to be lower than 0.2 . The minimum value of $\mathrm{CO}_{2}$ concentration is mainly affected by kinetic factors: the rate of the carbonation reaction, during the discharging phase, must sustain a relevant exothermic effect in order to produce a significant temperature increase of the gas stream along the reactor. From a preliminary kinetic analysis, the $\mathrm{CO}_{2}$ minimum molar fraction necessary to increase the temperature of the gaseous flow of $300{ }^{\circ} \mathrm{C}$ is about 0.05 . Therefore, a possible operating range for the $\mathrm{CO}_{2}$ molar fraction along the circuit, in the hypothesis of adiabatic reactor, is $0.05-0.2$; in the following it is conservatively assumed that the operating range is between 0.07 and 0.2 .

Table 6. Total equilibrium pressure of the $\mathrm{CaCO}_{3} \mathrm{CaO}$ system varying the molar $\mathrm{CO}_{2}$ fraction for two different temperature levels.

\begin{tabular}{cccc}
\hline$y_{\text {CO2 }}(\mathbf{m o l} / \mathbf{m o l})$ & $\boldsymbol{P}_{\text {tot }}(\mathbf{a t m}) @ \boldsymbol{T}_{\boldsymbol{e q}}\left({ }^{\circ} \mathbf{C}\right): \mathbf{9 0 0}$ & $\boldsymbol{y}_{\mathrm{CO} 2}(\mathbf{m o l} / \mathbf{m o l})$ & $\boldsymbol{P}_{\text {tot }}(\mathbf{a t m}) @ \boldsymbol{T}_{\boldsymbol{e q}}\left({ }^{\circ} \mathbf{C}\right): \mathbf{1 0 0 0}$ \\
\hline 0.1 & 10.73 & 0.1 & 42.28 \\
0.2 & 5.37 & 0.2 & 21.14 \\
0.3 & 3.58 & 0.3 & 14.09 \\
0.4 & 2.68 & 0.4 & 10.57 \\
0.5 & 2.15 & 0.5 & 8.46 \\
0.6 & 1.79 & 0.6 & 7.05 \\
0.7 & 1.53 & 0.7 & 6.04 \\
0.8 & 1.34 & 0.8 & 5.28 \\
0.9 & 1.19 & 0.9 & 4.70 \\
1 & 1.07 & 1 & 4.22 \\
\hline
\end{tabular}

In the case of a directly irradiated reactor, the maximum concentration limit is obviously greater: assuming a maximum equilibrium temperature of $1000{ }^{\circ} \mathrm{C}$ and a total pressure of about $5 \mathrm{~atm}$, the corresponding $\mathrm{CO}_{2}$ mole fraction is 0.8 (Table 6), with a significant reduction in storage volumes.

In the off-sun operating phase, shown in Figure $16 \mathrm{~b}$, the air $/ \mathrm{CO}_{2}$ mixture coming from the buffer is compressed, preheated, and then sent to the thermochemical storage unit, where the exothermic carbonation reaction occurs with the associated $\mathrm{CO}_{2}$ consumption and regeneration of the initial carbonate. The hot gas leaving the TCS unit is then processed in the power block (or in the two series power blocks) to produce electricity. Finally, downstream of the recuperator, the gas is cooled and cycled back to the compressor, enriched with a stream of air/ $\mathrm{CO}_{2}$ from the buffer to balance the molar flow rate in the circuit.

On the basis of the process diagrams shown in Figure 16a, and taking into account the thermodynamic properties of the $\mathrm{CaCO}_{3}-\mathrm{CaO}$ system (Figure 9), the nominal operating parameters of the TCS unit during charging and discharging steps were preliminarily identified, considering the $\mathrm{CO}_{2}$ concentration range mentioned above (0.07-0.2). Clearly in the real plant operation the system dynamically evolves within the two limit states characterized by the two $\mathrm{CO}_{2}$ limit concentrations, with gradual changes in operating conditions.

For the charging phase it was assumed to operate the system in the pressure range 1-4 atm; the storage of the $\mathrm{CO}_{2}$ produced is performed at 4 atm to reduce gas molar volumes.

In the discharging phase the system is operated at a higher pressure level to increase the temperature at which the accumulated heat is released and to improve the kinetics of the carbonation reaction; the optimal operating pressure was identified through the process analysis of the entire flow sheet represented in Figure 16b, taking into account the upstream and downstream operations of the TCS unit (for the recuperator the temperature difference between the inlet cold stream and the outlet hot stream was assumed equal to $50{ }^{\circ} \mathrm{C}$, while the power block was assimilated to a turbine with isoentropic efficiency equal to 0.85$)$. 
For both the $\mathrm{CO}_{2}$ concentration limits considered, a parametric analysis of the reactor operating conditions (outlet temperature and inlet air flow) was carried out varying the compressor outlet pressure, maintaining the reactor inlet temperature above $600{ }^{\circ} \mathrm{C}$ to favor the carbonation kinetics. The results of the parametric analysis are summarized in Figure 17, which also shows the equilibrium temperature of the system as a function of the total pressure.

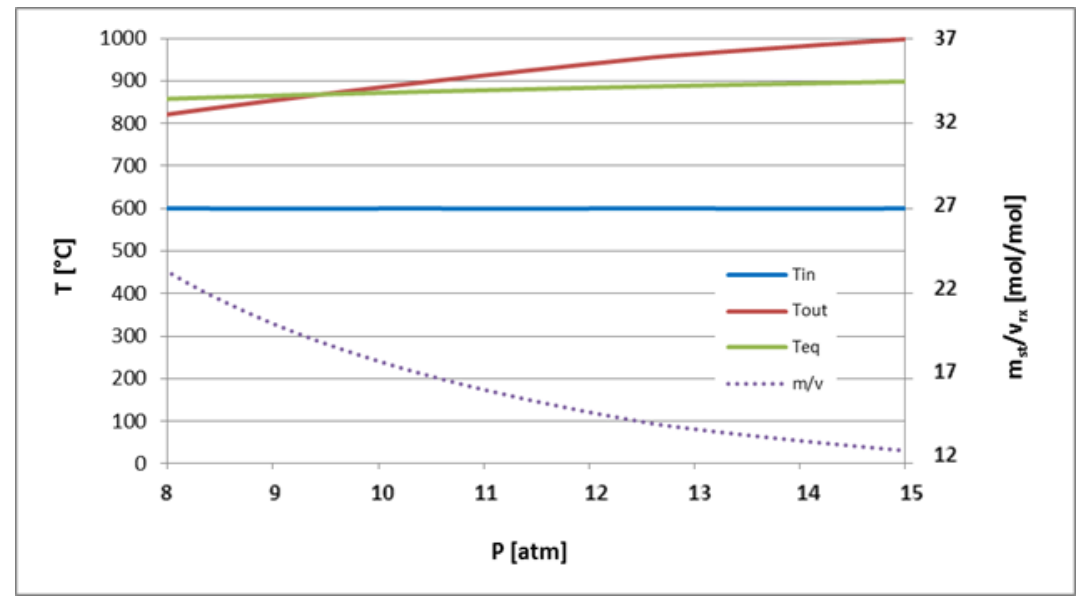

(a)

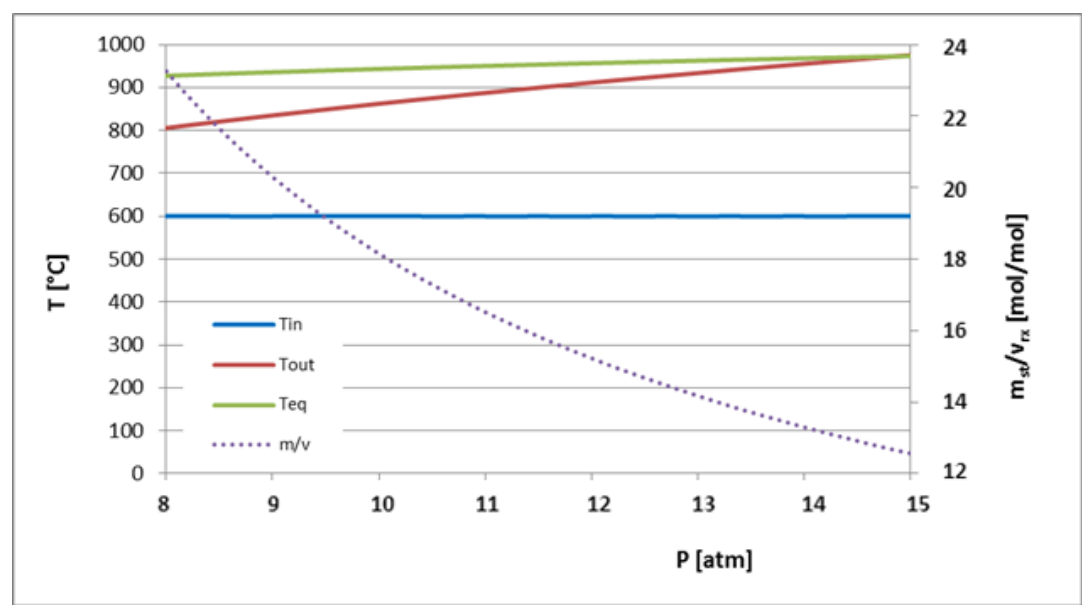

(b)

Figure 17. $\mathrm{CaCO}_{3}-\mathrm{CaO}$ reactor (discharging step, closed loop): parametric analysis of the inlet and outlet temperature and equilibrium temperature varying the inlet total pressure (power block outlet pressure: $4 \mathrm{~atm})$. (a) $\mathrm{x}_{\mathrm{CO} 2}: 0.2 ;$ (b) $\mathrm{x}_{\mathrm{CO} 2}: 0.07$.

The figure shows that, since the reactor operating temperature has to be lower than the equilibrium temperature for the exothermic reaction to proceed spontaneously, the maximum pressure value is $9 \mathrm{~atm}$ in the case of minimum $\mathrm{CO}_{2}$ molar fraction, and $14 \mathrm{~atm}$ in the case of higher $\mathrm{CO}_{2}$ concentration; Table 7 summarizes the main operating parameters identified for the charging and discharging phases in the two $\mathrm{CO}_{2}$ concentration limit conditions. In the discharging phase, clearly, the performance of the thermochemical system is better at high $\mathrm{CO}_{2}$ concentrations, reaching higher temperatures and releasing more heat per unit of inlet flow.

From an engineering point of view, this closed cycle scheme presents a series of limitations that have to be taken into account for a future technical feasibility analysis. Firstly the presence of a $\mathrm{CO}_{2}$ storage, both in the form of a compressed or condensed gas, implies high storage volumes and high investment and operative costs, actually reducing the potential duration of the thermal accumulation, probably suitable for daily or short-term applications. Furthermore the variable gas concentrations and volumes require a complex management of the plant operation and a sophisticated process control, which can limit the application perspectives. 
Table 7. TCS operating conditions for the carbonate-based system $\left(\mathrm{CaCO}_{3} \mathrm{Ca}\right)$ applied to a closed loop TCS unit.

\begin{tabular}{|c|c|c|c|c|}
\hline $\mathrm{CaCO}_{3}-\mathrm{CaO}$ System & \multicolumn{2}{|c|}{ Charging Phase } & \multicolumn{2}{|c|}{ Discharging Phase } \\
\hline \multicolumn{5}{|l|}{$\Delta H_{r x}: 178(\mathrm{~kJ} / \mathrm{mol})$} \\
\hline$x_{\mathrm{CO} 2 . \mathrm{in}}(\mathrm{mol} / \mathrm{mol})$ & 0.07 (min) & $0.2(\max )$ & $0.2(\max )$ & $0.07(\mathrm{~min})$ \\
\hline$P_{t o t, \text { in }}(\mathrm{atm})$ & 4.0 & 4.0 & 12 & 9 \\
\hline$T_{e q}\left({ }^{\circ} \mathrm{C}\right)$ & 817 & 880 & 957 & 866 \\
\hline$T_{\text {in }}\left({ }^{\circ} \mathrm{C}\right)$ & 1000 & 1000 & 600 & 600 \\
\hline$T_{\text {out }}\left({ }^{\circ} \mathrm{C}\right)$ & 827 & 890 & 911 & 854 \\
\hline$m_{s t} / v_{r x}\left(\mathrm{~mol}_{\text {gas }} / \mathrm{mol}_{\mathrm{s}}\right)$ & 28.9 & 41.9 & 15.2 & 20.2 \\
\hline$Q_{s t} / m_{s t}(\mathbf{k J} / \mathrm{mol})$ & 6.1 & 4.2 & 11.7 & 8.8 \\
\hline
\end{tabular}

\subsection{Open Loop Option: Calculation of TCS Operating Parameters}

In the case of an open cycle, in the solar operating phase (Figure 18a) the atmospheric air, downstream of a compression stage, is sent to the receiver to absorb the solar radiation. The flow of hot air leaving the receiver is partly processed directly in the power block and partly sent to the thermochemical storage unit (consisting of modular elements) to power the endothermic calcium carbonate calcination reaction (with $\mathrm{CO}_{2}$ release). Finally, through a recuperator, the gas exiting the power block preheats the incoming air before being released into the atmosphere or treated in some $\mathrm{CO}_{2}$ capture and segregation process. It is worth underlining that the whole process is characterized by a neutral $\mathrm{CO}_{2}$ balance, since the carbon dioxide released during the solar operating phase has been previously absorbed by $\mathrm{CaO}$, during off-sun operation, from gaseous effluents of combustion and/or oxy-combustion processes (Figure 18b).

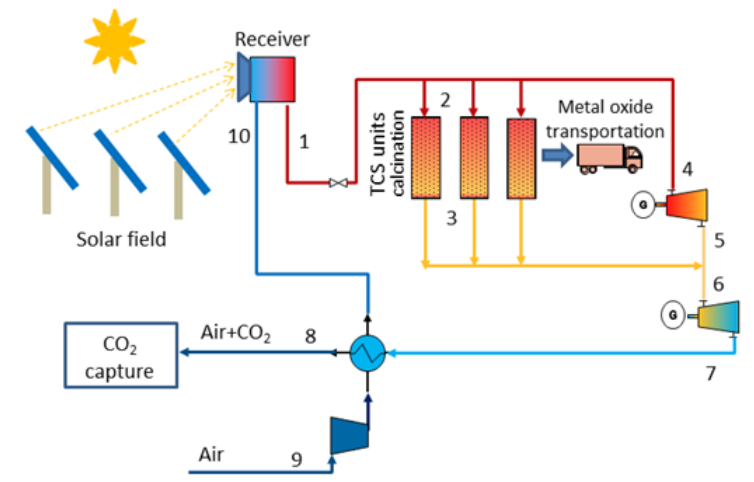

(a)

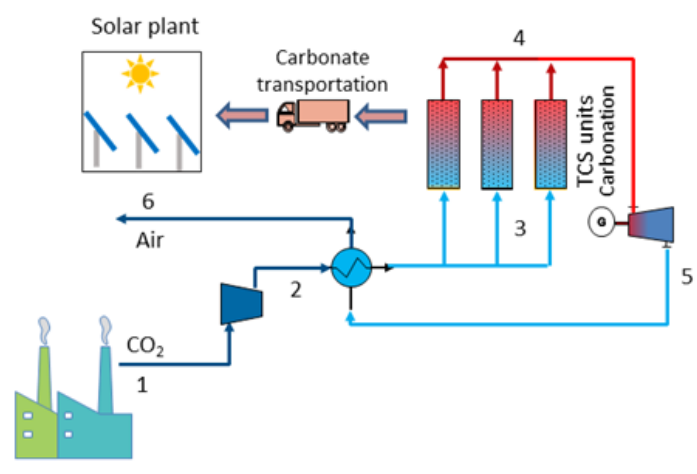

(b)

Figure 18. Conceptual scheme for the integration of central tower plant and TCS storage unit assuming adiabatic reactor, open process configuration, Brayton cycle-based power block. (a) on-sun operation; (b) off-sun operation.

In the discharging phase, shown in Figure $18 \mathrm{~b}$, the air $/ \mathrm{CO}_{2}$ mixture coming from thermoelectric plants, or in any case from fossil combustion processes, is preheated and then sent to the TCS unit, where the exothermic carbonation reaction takes place with associated consumption of $\mathrm{CO}_{2}$ and regeneration of the initial carbonate. The hot gas leaving the TCS unit is processed in the power block for the production of electricity and then sent to the recuperator to preheat the inlet gas flow. On the basis of the process diagram shown in Figure 18a, and taking into account the thermodynamic properties of the system under examination (Figure 9), during the on-sun phase it is assumed to operate the TCS system at a pressure of $4 \mathrm{~atm}$ (Teq: $580^{\circ} \mathrm{C}$ ). Assuming that a reactor outlet temperature of $700{ }^{\circ} \mathrm{C}$ guarantees sufficiently high reaction kinetics [51], the temperature difference between the upstream and downstream of the reactor is higher than the closed cycle option $\left(1000-700{ }^{\circ} \mathrm{C}\right.$ vs. 1000-900 ${ }^{\circ} \mathrm{C}$ ), leading to a more efficient solar energy storage. 
In the discharging phase (Figure 18b), the system is operated at a higher pressure than the charging step to increase the thermal level at which the stored heat is released and to improve the kinetics of the carbonation reaction. Additionally, in this case the optimal operating pressure was identified through the process analysis of the entire flowsheet, taking into account the operating specifications of the compressor, recuperator and power block. In particular, for the recuperator, a temperature difference of $50^{\circ} \mathrm{C}$ between the inlet cold stream and the outlet hot stream was assumed, while the power block was assimilated to a turbine with isoentropic efficiency equal to 0.85 . In the analysis, three different levels of $\mathrm{CO}_{2}$ concentration in the inlet effluent were considered, and a reactor inlet temperature of $500{ }^{\circ} \mathrm{C}$ was assumed to have a reasonable carbonation reaction rate [51].

The results of the parametric analysis of the reactor operating conditions varying the compressor outlet pressure are reported in Figure 19, where the outlet temperature of the reactor is shown along with the equilibrium temperature of the reactive system and the ratio between the flow rate of the inlet gas and the reaction rate $\left(m_{s t} / v_{r x}\right)$.

The figure shows that, since the reactor operating temperature has to be lower than the equilibrium temperature to favor the exothermic reaction, the maximum pressure value is comprised in the range 3-3.8 atm, depending on the $\mathrm{CO}_{2}$ inlet concentration. Table 8 summarizes the main TCS operating parameters identified for the charging and discharging phases at the three $\mathrm{CO}_{2}$ concentration levels considered $(0.07,0.1$, and 0.13$)$. In the discharging phase, clearly, the thermochemical system performs better at high concentrations of $\mathrm{CO}_{2}$, reaching higher reactor temperatures and releasing a larger amount of thermal energy per mole of gas (from 9.5 to $11.8 \mathrm{~kJ} / \mathrm{mol}$ ). From the comparison with the closed cycle option (Table 7), it emerges that the open system is strongly favored in the charging phase, with an almost double storage potential ( $Q_{s t} / m_{s t}$ equal to 8.8 against $\left.4.25-6.15 \mathrm{~kJ} / \mathrm{mol}\right)$, while the performances in the discharging phase are quite aligned.

From a practical point of view, the open cycle scheme requires a less complex plant configuration and a less sophisticated control system than the closed one, which deals with variable gas concentrations and volumes. Furthermore the open scheme can enlarge the application field of thermochemical storage to the energy efficiency and thermal energy recovery in existing plant powered by fossil fuels, enabling a spatially and thermally decoupling between the charging and discharging steps.

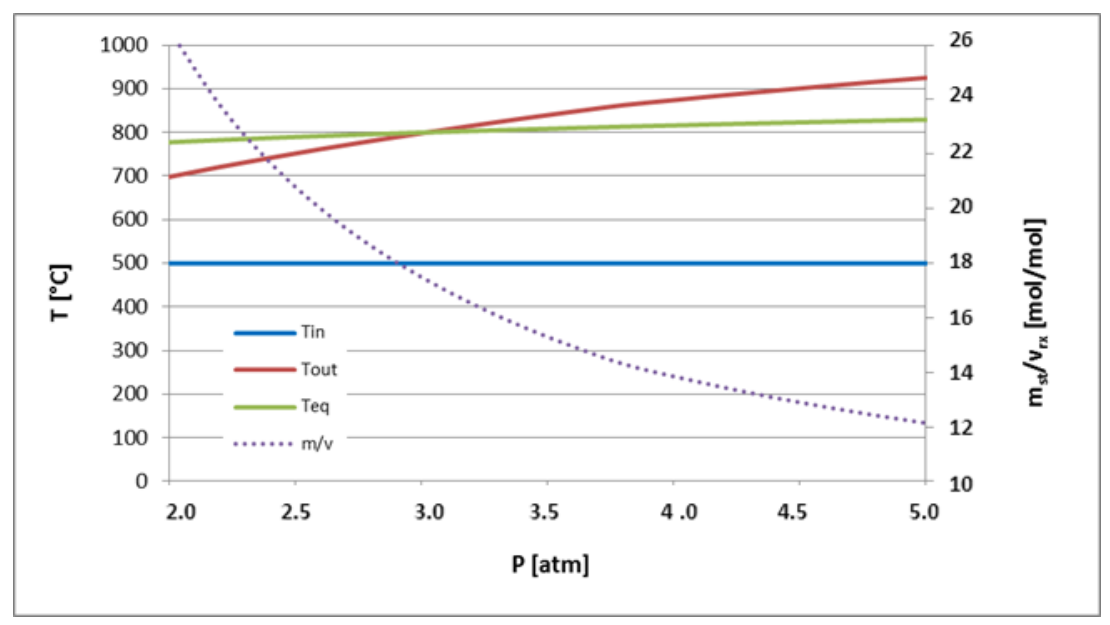

Figure 19. Cont. 


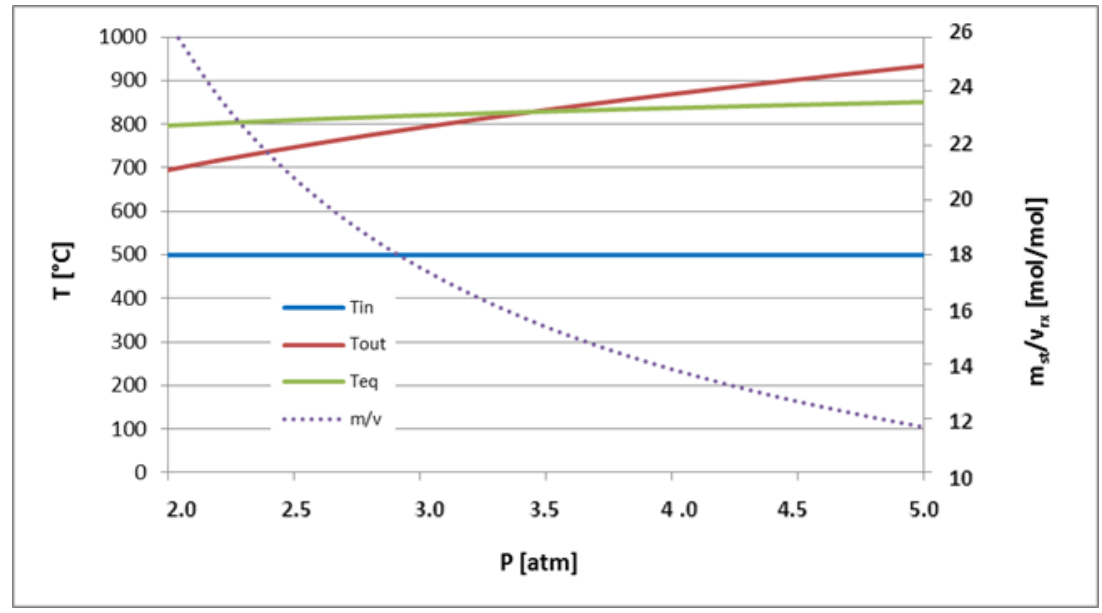

(b)

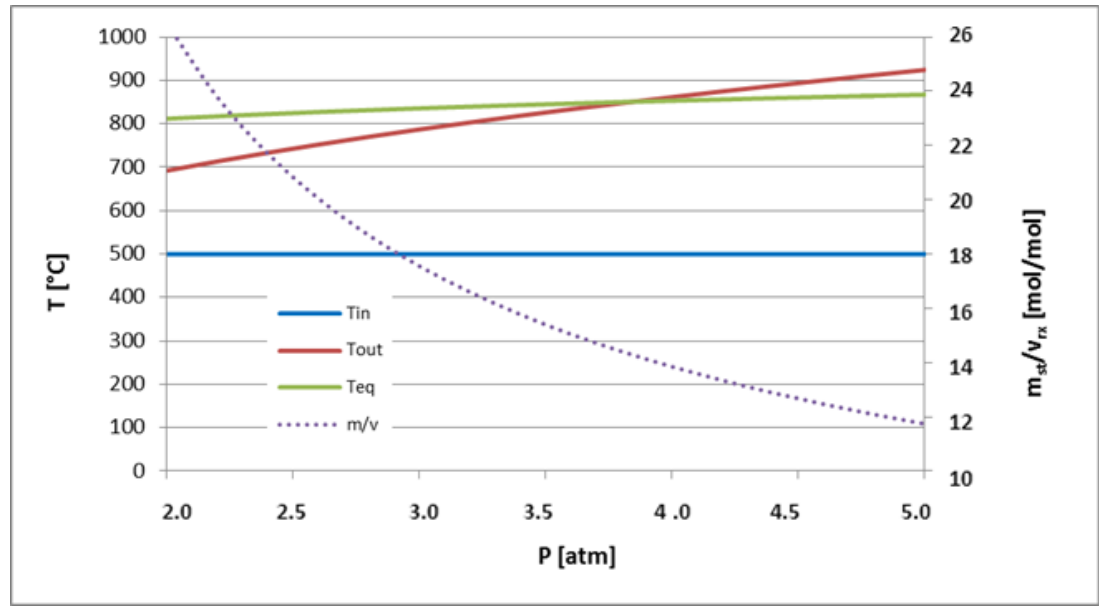

(c)

Figure 19. $\mathrm{CaCO}_{3} \mathrm{CaO}$ reactor (discharging step and open loop): parametric analysis of the inlet and outlet temperature and equilibrium temperature varying the inlet total pressure (power block outlet pressure: $1 \mathrm{~atm})$. (a) $\mathrm{x}_{\mathrm{CO} 2}: 0.07 ;$ (b) $\mathrm{x}_{\mathrm{CO} 2}: 0.1 ;$ (c) $\mathrm{x}_{\mathrm{CO} 2}: 0.13$.

Table 8. TCS operating conditions for the carbonate-based system $\left(\mathrm{CaCO}_{3} \mathrm{CaO}\right)$ applied to an open loop process: in the discharging phase, three possible scenarios are analyzed, associated to three different $\mathrm{CO}_{2}$ concentrations of the inlet gas flow.

\begin{tabular}{|c|c|c|c|c|}
\hline $\mathrm{CaCO}_{3}-\mathrm{CaO}$ System & Charging Phase & \multicolumn{3}{|c|}{ Discharging Phase } \\
\hline \multicolumn{5}{|l|}{$\Delta H_{r x}: 178(\mathrm{~kJ} / \mathrm{mol})$} \\
\hline$x_{\text {CO2.in }}(\mathrm{mol} / \mathrm{mol})$ & $<0.001$ & 0.07 & 0.10 & 0.13 \\
\hline$P_{t o t, i n}(a t m)$ & 10 & 2.8 & 3.2 & 3.6 \\
\hline$T_{e q}\left({ }^{\circ} \mathrm{C}\right)$ & 615 & 817 & 824 & 847 \\
\hline$T_{\text {in }}\left({ }^{\circ} \mathrm{C}\right)$ & 1000 & 500 & 500 & 500 \\
\hline$T_{\text {out }}\left({ }^{\circ} \mathrm{C}\right)$ & 700 & 780 & 809 & 833 \\
\hline$m_{s t} / v_{r x}\left(\mathrm{~mol}_{\text {gas }} / \mathrm{mol}_{\mathrm{s}}\right)$ & 20.2 & 18.6 & 16.5 & 15.04 \\
\hline$Q_{s t} / m_{s t}(\mathbf{k J} / \mathrm{mol})$ & 8.8 & 9.5 & 10.7 & 11.8 \\
\hline
\end{tabular}

\section{Conclusions}

In the present work a theoretical analysis was carried out to identify possible integration approaches between solar plants and thermo-chemical systems in view of long-term energy storage. The study was focused on high temperature solar plants (solar towers) using gaseous heat transfer fluids. Two categories of compatible reactive materials were identified: metal oxides and carbonates. More specifically, cobalt oxides, manganese oxides, and the calcium carbonate/calcium oxide system were selected. For the metal oxide systems, two possible schemes for the TCS unit were analyzed: 
in a first scheme, direct heat exchange between the heat transfer fluid and the reactive material was assumed, while, in the second scheme, a heat exchanger was used to transfer the solar energy to the process fluid. From the comparison of the process parameters, a higher storage efficiency for the direct exchange scheme was obtained. On the other hand, in the direct contact scheme, the constraints on the reactor operating pressure entail significant limitations on the overall system efficiency. This can be solved by adopting two different solar receivers and two separate HTF circuits, one dedicated to thermal storage and the other one to the production of electricity. The two receivers, operating at different pressures, could be positioned in separate sections of the same solar tower, intercepting the reflected radiation from two different areas of the solar field.

For TCS units based on the calcium carbonate/calcium oxide system, two plant configurations were analyzed. As a first option, a closed process, including a $\mathrm{CO}_{2}$ buffer tank to compensate for the cyclical release and absorption of $\mathrm{CO}_{2}$, was considered. As a second option, an open process was envisaged, with the calcination step carried out in air flow to reduce the reaction temperature (from $900{ }^{\circ} \mathrm{C}$ to $700{ }^{\circ} \mathrm{C}$ ), and the carbonation step performed through the use of a gaseous stream containing $\mathrm{CO}_{2}$. In this latter option, the heat storage and release steps can also, in principle, take place at different sites, taking advantage of a locally available $\mathrm{CO}_{2}$ source, such as a combustion and/or oxy-combustion plant, for the thermal discharging (carbonation) step. In this respect, it is worth pointing out that coupling the combustion and TCS processes does not affect the overall $\mathrm{CO}_{2}$ balance, since the carbon dioxide released during solar heating has been previously absorbed from gaseous effluents in the off-sun operation. On the contrary, with this configuration, the process could also be used as a carbon capture solution.

From the comparison of the operating conditions of the two process options (closed and open) it emerges that the open configuration is strongly favored in the charging phase and can achieve an almost double thermal storage rate by using the same air flowrate $\left(8.8\right.$ against $4.25 \mathrm{~kW}$ per $1 \mathrm{~mol} \mathrm{~s}^{-1}$ air flowrate). Moreover, the closed cycle option is more complex, especially in terms of process control, due to the variable gas concentrations and volumes. In addition, the need to provide the system with a gas storage, as well as solid storage, makes this solution more suitable for a daily or non-seasonal thermal accumulation.

Anyway, the exact quantification of the benefits and limitations of the plant schemes here presented is beyond the scope of this work, which is aimed at identifying possible coupling solutions between CSP plants and thermochemical storage systems. In order to compare the performance and characteristics of the different TCS systems here considered, the dynamics of the charging and discharging processes should be accounted for, in order to evaluate the actual storage capacity of the materials. Therefore, as a future development of the work, an experimental campaign on the selected materials (in particular calcium carbonate) will be carried out to test the reactions kinetics in the identified operating conditions and to implement modelling tools to describe the dynamics of the TCS unit.

Author Contributions: Data curation, S.S. and M.A.M.; Funding acquisition, R.L.; Investigation, M.L. and S.C.; Methodology, M.L.; Project administration, R.L.; Supervision, M.C.A.; Writing-review \& editing, L.T. and M.A.M. All authors have read and agreed to the published version of the manuscript.

Funding: This research was funded by the Italian Ministry of Economic Development through the Research of Electric System-PTR 2019-21—Objective: Technologies-Project 1.2/WP2.

Conflicts of Interest: The authors declare no conflict of interest.

\section{References}

1. Glatzmaier, G. Summary Report for Concentrating Solar Power Thermal Storage Workshop; Technical Report NREL/TP- 5500-52134; Contract No. DE-AC36-08GO28308; National Renewable Energy Lab.: Golden, CO, USA, August 2011.

2. Liberatore, R.; Lanchi, M.; Turchetti, L. Hydrogen production by the solar-powered hybrid sulfur process: Analysis of the integration of the CSP and chemical plants in selected scenarios. AIP Conf. Proc. 2016, 1734, 120006. 
3. Juan, W.; Xin, F. Research progress of solar thermochemical energy. Int. J. Energy Res. 2015, 39, 869-888.

4. Agrafiotis, C.; Tescari, S.; Roeb, M.; Sattler, C. Oxides and porous structures based on earth-abundant elements for hybrid sensible/thermochemical solar energy storage in air-operated solar thermal power plants. AIP Conf. Proc. 2018, 2033, 100001.

5. Pagkoura, C.; Karagiannakis, G.; Zygogianni, A.; Lorentzou, S.; Kostoglou, M.; Konstandopoulos, A.G.; Rattenburry, M.; Woodhead, J.W. Cobalt oxide based structured bodies as redox thermochemical heat storage medium for future CSP plants. Solar Energy 2014, 108, 146-163. [CrossRef]

6. Chueh, W.C.; Falter, C.; Abbott, M.; Scipio, D.; Furler, P.; Haile, S.M.; Steinfeld, A. High-flux solar-driven thermochemical dissociation of $\mathrm{CO}_{2}$ and $\mathrm{H}_{2} \mathrm{O}$ using nonstoichiometric ceria. Science 2010, 330, 1797-1801. [CrossRef]

7. Linder, M.; Roßkopf, C.; Schmidt, M.; Wörner, A. Thermochemical energy storage in kW-scale based on $\mathrm{CaO} / \mathrm{Ca}(\mathrm{OH}) 2$. Energy Procedia 2014, 49, 888-897. [CrossRef]

8. Flegkas, S.; Birkelbach, F.; Winter, F.; Groenewold, H.; Werner, A. Profitability Analysis and Capital Cost Estimation of a Thermochemical Energy Storage System Utilizing Fluidized Bed Reactors and the Reaction System $\mathrm{MgO} / \mathrm{Mg}(\mathrm{OH})_{2}$. Energies 2019, 12, 4788. [CrossRef]

9. Kyaw, K.; Matsuda, H.; Hasatani, M. Applicability of carbonation/decarbonation reactions to high-temperature. Thermal energy storage and temperature upgrading. J. Chem. Eng. Jpn. 1996, 29, 119-125.

10. Kubota, M.; Kyaw, K.; Watanabe, F.; Matsuda, H.; Hasatani, H. Study of decarbonation of $\mathrm{CaCO}_{3}$ for high temperature thermal energy storage. J. Chem. Eng. Jpn. 2000, 33, 797-800. [CrossRef]

11. Shkatulov, A.I.; Kim, S.T.; Miura, H.; Kato, Y.; Aristov, Y.I. Adapting the MgO-CO2 working pair for thermochemical energy storage by doping with salts. Energy Convers. Manag. 2019, 185, 473-481. [CrossRef]

12. André, L.; Abanades, S.; Cassayre, L. Mixed Metal Oxide Systems Applied to Thermochemical Storage of Solar Energy: Benefits of Secondary Metal Addition in Co and Mn Oxides and Contribution of Thermodynamics. Appl. Sci. 2018, 8, 2618. [CrossRef]

13. Kim, S.T.; Miura, H.; Takasu, H.; Kato, Y.; Shkatulov, A.; Aristov, Y. Adapting the $\mathrm{MgO}-\mathrm{CO}_{2}$ working pair for thermochemical energy storage by doping with salts: Effect of the (LIK)NO 3 content. Energies 2019, 12, 2262. [CrossRef]

14. Zsembinszki, G.; Solé, A.; Barreneche, C.; Prieto, C.; Fernandez, A.I.; Cabeza, L. Review of Reactors with Potential Use in Thermochemical Energy Storage in Concentrated Solar Power Plants. Energies 2018, 11, 2358. [CrossRef]

15. Preisner, N.C.; Linder, M. A Moving Bed Reactor for Thermochemical Energy Storage Based on Metal Oxides. Energies 2020, 13, 1232. [CrossRef]

16. Preisner, N.C.; Buerger, I.; Wokon, M.; Linder, M. Numerical Investigations of a Counter-Current Moving Bed Reactor for Thermochemical Energy Storage at High Temperatures. Energies 2020, 13, 772. [CrossRef]

17. Tescari, S.; Singh, A.; De Oliveira, L.; Breuer, S.; Agrafiotis, C.; Roeb, M.; Sattler, C.; Marcher, J.; Pagkoura, C.; Karagiannakis, G.; et al. Experimental proof of concept of a pilot-scale thermochemical storage unit. AIP Conf. Proc. 2017, 1850, 090006. [CrossRef]

18. Schmidt, M.; Szczukowski, C.; Roßkopf, C.; Linder, M.; Wörner, A. Experimental results of a $10 \mathrm{~kW}$ high temperature thermochemical storage reactor based on calcium hydroxide. Appl. Therm. Eng. 2014, 62, 553-559. [CrossRef]

19. Strohle, S.; Haselbacher, A.; Jovanovic, Z.R.; Steinfeld, A. The effect of the gas-solid contacting pattern in a high-temperature thermochemical energy storage on the performance of a concentrated solar power plant. Energy Environ. Sci. 2016, 9, 1375-1389. [CrossRef]

20. Vignarooban, K.; Xu, X.; Arvay, A.; Hsu, K.; Kannan, A.M. Heat transfer fluids for concentrating power systems-A review. Appl. Energy 2015, 146, 383-396. [CrossRef]

21. Heller, L. Literature Review on Heat Transfer Fluids and Thermal Energy Storage Systems in CSP Plants. STERG Report. 2013. Available online: http://sterg.sun.ac.za/wp-content/uploads/2011/08/HTF_TESmed_ Review_2013_05_311.pdf (accessed on 1 July 2020).

22. Bonk, A.; Sau, S.; Uranga, N.; Hernaiz, M.; Bauer, T. Advanced heat transfer fluids for direct molten salt line-focusing CSP plants. Prog. Energy Combust. 2018, 67, 1339-1351. [CrossRef]

23. Río, P.; Peñasco, C.; Mir-Artigues, P. An overview of drivers and barriers to concentrated solar power in the European Union. Renew. Sust. Energy Rev. 2018, 81, 1019-1029. 
24. Pramanik, S.; Ravikrishna, R.V. A review of concentrated solar power hybrid technologies. Sol. Energy 2017, 156, 113-132. [CrossRef]

25. Hon, C.K.; Iverson, B.D. Review of high-temperature central receiver designs for concentrating solar power. Renew. Sust. Energy Rev. 2014, 29, 835-846.

26. Roeb, M.; Sattler, C.; Klüser, R.; Monnerie, N.; de Oliveira, L.; Konstandopoulos, A.G.; Agrafiotis, C.; Zaspalis, V.T.; Nalbandian, N.; Steel, A.; et al. Solar hydrogen production by a two-step cycle based on mixed iron oxides. J. Sol. Energy Eng. 2016, 128, 125-133. [CrossRef]

27. Gil, A.; Medrano, M.; Martorell, I.; Lizaro, A.; Dolado, P.; Zalba, B.; Cabeza, L.F. State of the art on high temperature energy storage for power generation. Part I-Concepts, materials and modellization. Renew. Sust. Energy Rev. 2010, 14, 31-55. [CrossRef]

28. IRENA. Renewable Energy Technologies: Cost Analysis Series. Irena working paper. Sol. Photovolt 2012, 1, 52 .

29. Steinfeld, A.; Palumbo, R. Solar thermochemical process technology. Encycl. Phys. Sci. Technol. 2001, 15, 237-256.

30. Barin, I. Thermochemical Data of Pure Substances, 3rd ed.; Wiley: Hoboken, NJ, USA, 1997.

31. Chase, M.W. NIST-JANAF Thermochemical Tables, 4th ed.; American Institute of Physics: College Park, MD, USA, 1998.

32. McBride, B.J.; Gordon, S.; Reno, M.A. Coefficients for Calculation Thermodynamic and Transport Properties of Individual Species. NASA Technical Memorandum 4513. 1993. Available online: https://ntrs.nasa.gov/ search.jsp?R=19940013151-2018-01-23T13:34:13+00:00Z (accessed on 1 July 2020).

33. Robie, R.A.; Hemingway, B.S.; Fisher, J.R. Thermodynamic Properties of Minerals and Related Substances at 298.15 K and 1 bar (105 Pascals) Pressure and at Higher Temperatures; Geological Survey Bulletin: Washington, DC, USA, 1979. [CrossRef]

34. GA. Thermochemical Heat Storage for Concentrated Solar Power; Final Report n. GA-C27137; GA: San Diego, CA, USA, 2011.

35. Wentworth, W.E.; Chen, E. Simple thermal decomposition reactions for storage of solar thermal energy. Sol. Energy 1976, 9, 205-214. [CrossRef]

36. Carrillo, A.J.; Moya, J.; Bayón, A.; Jana, P.; Víctor, A.; Romero, M.; Gonzalez-Aguilar, J.; Serrano, D.P.; Pizarro, P.; Coronado, J.M. Thermochemical energy storage at high temperature via redox cycles of Mn and Co oxides: Pure oxides versus mixed ones. Sol. Energy Mat. Sol. Cells 2014, 123, 47-57. [CrossRef]

37. Hutchings, K.N.; Wilson, M.; Larsen, P.A.; Cutler, R.A. Kinetic and thermodynamic considerations for oxygen absorption/desorption using cobalt oxide. Solid State Ionics 2006, 177, 45-51. [CrossRef]

38. Schrader, A.J.; Muroyama, A.P.; Loutzenhiser, P.G. Solar electricity via an air Brayton cycle with an integrated two-step thermochemical cycle for heat storage based on $\mathrm{Co}_{3} \mathrm{O}_{4} / \mathrm{CoO}$ redox reactions: Thermodynamic analysis. Sol. Energy 2015, 118, 485-495. [CrossRef]

39. Neises, M.; Tescari, S.; De Oliveira, L.; Roeb, M.; Sattler, C.; Wong, B. Solar-heated rotary kiln for thermochemical energy storage. Sol. Energy 2012, 86, 3040-3048. [CrossRef]

40. Carrillo, A.J.; Serrano, D.P.; Pizarro, P.; Coronado, J.M. Design of efficient Mn-based redox materials for thermochemical heat storage at high temperatures. SolarPACES 2015. AIP Conf. Proc. 2016, 1734. [CrossRef]

41. Stendardo, S.; Foscolo, P.U. Carbon dioxide capture with dolomite: A model for gas-solid reaction within the grains of a particulate sorbent. Chem. Eng. Sci. 2009, 64, 2343-2352. [CrossRef]

42. Agrafiotis, C.; Roeb, M.; Schmücker, M.; Sattler, C. Exploitation of thermochemical cycles based on solid oxide redox systems for thermochemical storage of solar heat. Part 1: Testing of cobalt oxide-based powders. Sol. Energy 2014, 102, 189-211. [CrossRef]

43. Agrafiotis, C.; Roeb, M.; Schmücker, M.; Sattler, C. Exploitation of thermochemical cycles based on solid oxide redox systems for thermochemical storage of solar heat. Part 2: Redox oxide-coated porous ceramic structures as integrated thermochemical reactors/heat exchangers. Sol. Energy 2015, 114, 440-458. [CrossRef]

44. Stendardo, S.; Andersen, L.K.; Herce, C. Self-activation and effect of regeneration conditions in $\mathrm{CO}_{2}-\mathrm{Carbonate}$ looping with $\mathrm{CaO}-\mathrm{Ca}_{12} \mathrm{Al}_{14} \mathrm{O}_{33}$ sorbent. Chem. Eng. J. 2013, 220, 383-394. [CrossRef]

45. Meier, A.; Bonaldi, E.; Cella, G.M.; Lipinski, W.; Wuillemin, D.; Palumbo, R. Design and experimental investigation of a horizontal rotary reactor for the solar thermal production of lime. Energy 2004, 29, 811-821. [CrossRef] 
46. Agrafiotis, C.; de Oliveira, L.; Roeb, M.; Sattler, C. A solar receiver-storage modular cascade based on porous ceramic structures for hybrid sensible/thermochemical solar energy storage. SolarPACES 2015. AIP Conf. Proc. 2016, 1734, 050001. [CrossRef]

47. Kodama, T.; Gokon, N.; Seok Cho, H.; Matsubara, K.; Etori, T.; Takeuchi, A.; Yokota, S.; Ito, S. Particles fluidized bed receiver/reactor with a beam-down solar concentrating optics: 30-kWth performance test using a big sun-simulator. SolarPACES 2015. AIP Conf. Proc. 2016, 1734, 120004. [CrossRef]

48. Koepf, E.; Advani, S.G.; Steinfeld, A.; Prasad, A.K. A novel beam-down, gravity-fed, solar thermochemical receiver/reactor for direct solid particle decomposition: Design, modeling, and experimentation. Int. J. Hydrogen Energy 2012, 37, 16871-16887. [CrossRef]

49. Muroyama, A.P.; Schrader, A.J.; Loutzenhiser, P.G. Solar electricity via an Air Brayton cycle with an integrated two-step thermochemical cycle for heat storage based on $\mathrm{Co}_{3} \mathrm{O}_{4} / \mathrm{CoO}$ redox reactions II: Kinetic analyses. Sol. Energy 2015, 122, 409-418. [CrossRef]

50. Stanmore, B.R.; Gilot, P. Calcination and carbonation of limestone during thermal cycling for $\mathrm{CO}_{2}$ sequestration. Fuel Process. Technol. 2005, 86, 1707-1743. [CrossRef]

51. Rouchon, L.; Favergeon, L.; Pijolat, M. New kinetic model for the rapid step of calcium oxide carbonation by carbon dioxide. J. Therm. Anal. Calorim. 2014, 116, 1181-1188. [CrossRef]

(C) 2020 by the authors. Licensee MDPI, Basel, Switzerland. This article is an open access article distributed under the terms and conditions of the Creative Commons Attribution (CC BY) license (http://creativecommons.org/licenses/by/4.0/). 